NASA/TM-2011-216958

\title{
Flow Field Characterization of an Angled Supersonic Jet Near a Bluff Body
}

John D. Wolter

Glenn Research Center, Cleveland, Ohio

Robert Childs

ELORET Corporation, Moffett Field, California

Mark P. Wernet

Glenn Research Center, Cleveland, Ohio

Andrea Shestopalov

ELORET Corporation, Moffett Field, California

John E. Melton

Ames Research Center, Moffett Field, California 


\section{NASA STI Program . . . in Profile}

Since its founding, NASA has been dedicated to the advancement of aeronautics and space science. The NASA Scientific and Technical Information (STI) program plays a key part in helping NASA maintain this important role.

The NASA STI Program operates under the auspices of the Agency Chief Information Officer. It collects, organizes, provides for archiving, and disseminates NASA's STI. The NASA STI program provides access to the NASA Aeronautics and Space Database and its public interface, the NASA Technical Reports Server, thus providing one of the largest collections of aeronautical and space science STI in the world. Results are published in both non-NASA channels and by NASA in the NASA STI Report Series, which includes the following report types:

- TECHNICAL PUBLICATION. Reports of completed research or a major significant phase of research that present the results of NASA programs and include extensive data or theoretical analysis. Includes compilations of significant scientific and technical data and information deemed to be of continuing reference value. NASA counterpart of peer-reviewed formal professional papers but has less stringent limitations on manuscript length and extent of graphic presentations.

- TECHNICAL MEMORANDUM. Scientific and technical findings that are preliminary or of specialized interest, e.g., quick release reports, working papers, and bibliographies that contain minimal annotation. Does not contain extensive analysis.

- CONTRACTOR REPORT. Scientific and technical findings by NASA-sponsored contractors and grantees.
- CONFERENCE PUBLICATION. Collected papers from scientific and technical conferences, symposia, seminars, or other meetings sponsored or cosponsored by NASA.

- SPECIAL PUBLICATION. Scientific, technical, or historical information from NASA programs, projects, and missions, often concerned with subjects having substantial public interest.

- TECHNICAL TRANSLATION. Englishlanguage translations of foreign scientific and technical material pertinent to NASA's mission.

Specialized services also include creating custom thesauri, building customized databases, organizing and publishing research results.

For more information about the NASA STI program, see the following:

- Access the NASA STI program home page at http://www.sti.nasa.gov

- E-mail your question via the Internet to help@ sti.nasa.gov

- Fax your question to the NASA STI Help Desk at $443-757-5803$

- Telephone the NASA STI Help Desk at 443-757-5802

- Write to: NASA Center for AeroSpace Information (CASI) 7115 Standard Drive Hanover, MD 21076-1320 
NASA/TM-2011-216958

AIAA-2010-4829

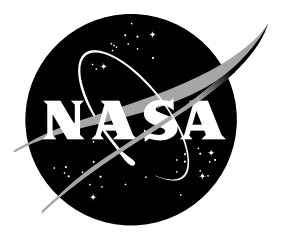

\section{Flow Field Characterization of an Angled Supersonic Jet Near a Bluff Body}

John D. Wolter

Glenn Research Center, Cleveland, Ohio

Robert Childs

ELORET Corporation, Moffett Field, California

Mark P. Wernet

Glenn Research Center, Cleveland, Ohio

Andrea Shestopalov

ELORET Corporation, Moffett Field, California

John E. Melton

Ames Research Center, Moffett Field, California

Prepared for the

28th Applied Aerodynamics Conference

sponsored by the American Institute of Aeronautics and Astronautics

Chicago, Illinois, June 28-July 1, 2010

National Aeronautics and

Space Administration

Glenn Research Center

Cleveland, Ohio 44135 
Level of Review: This material has been technically reviewed by technical management.

Available from

NASA Center for Aerospace Information

7115 Standard Drive

Hanover, MD 21076-1320
National Technical Information Service 5301 Shawnee Road Alexandria, VA 22312

Available electronically at http://gltrs.grc.nasa.gov 


\title{
Flow Field Characterization of an Angled Supersonic Jet Near a Bluff Body
}

\author{
John D. Wolter \\ National Aeronautics and Space Administration \\ Glenn Research Center \\ Cleveland, Ohio 44135 \\ Robert Childs* \\ ELORET Corporation \\ Moffett Field, California 94035 \\ Mark P. Wernet \\ National Aeronautics and Space Administration \\ Glenn Research Center \\ Cleveland, Ohio 44135 \\ Andrea Shestopalov ${ }^{\dagger}$ \\ ELORET Corporation \\ Moffett Field, California 94035 \\ John E. Melton \\ National Aeronautics and Space Administration \\ Ames Research Center \\ Moffett Field, California 94035
}

\begin{abstract}
An experiment was performed to acquire data from a hot supersonic jet in cross flow for the purpose of validating computational fluid dynamics (CFD) turbulence modeling relevant to the Orion Launch Abort System. Hot jet conditions were at the highest temperature and pressure that could be acquired in the test facility. The nozzle pressure ratio was 28.5 , and the nozzle temperature ratio was 3 . These conditions are different from those of the flight vehicle, but sufficiently high to model the observed turbulence features. Stereo Particle Image Velocimetry (SPIV) data and capsule pressure data are presented. Features of the flow field are presented and discussed.
\end{abstract}

\section{Nomenclature}

$\begin{array}{ll}\text { AAPL } & \text { Aero-Acoustic Propulsion Laboratory } \\ \text { AM } & \text { Abort Motor } \\ \text { CEV } & \text { Crew Exploration Vehicle } \\ \text { CFD } & \text { Computational Fluid Dynamics } \\ \text { C }_{X} & \text { Axial force coefficient } \\ \text { HFJER } & \text { High Flow Jet Exit Rig } \\ \text { LAV } & \text { Launch Abort Vehicle } \\ \text { NATR } & \text { Nozzle Aeroacoustic Test Rig } \\ \text { SPIV } & \text { Stereo Particle Image Velocimetry } \\ \varphi & \text { Azimuthal angle }\end{array}$

${ }^{*}$ Currently with Science \& Technology Corporation, Moffett Field, California 94035.

${ }^{\dagger}$ Currently with Exa Corporation, Burlington, Massachusetts 01803. 


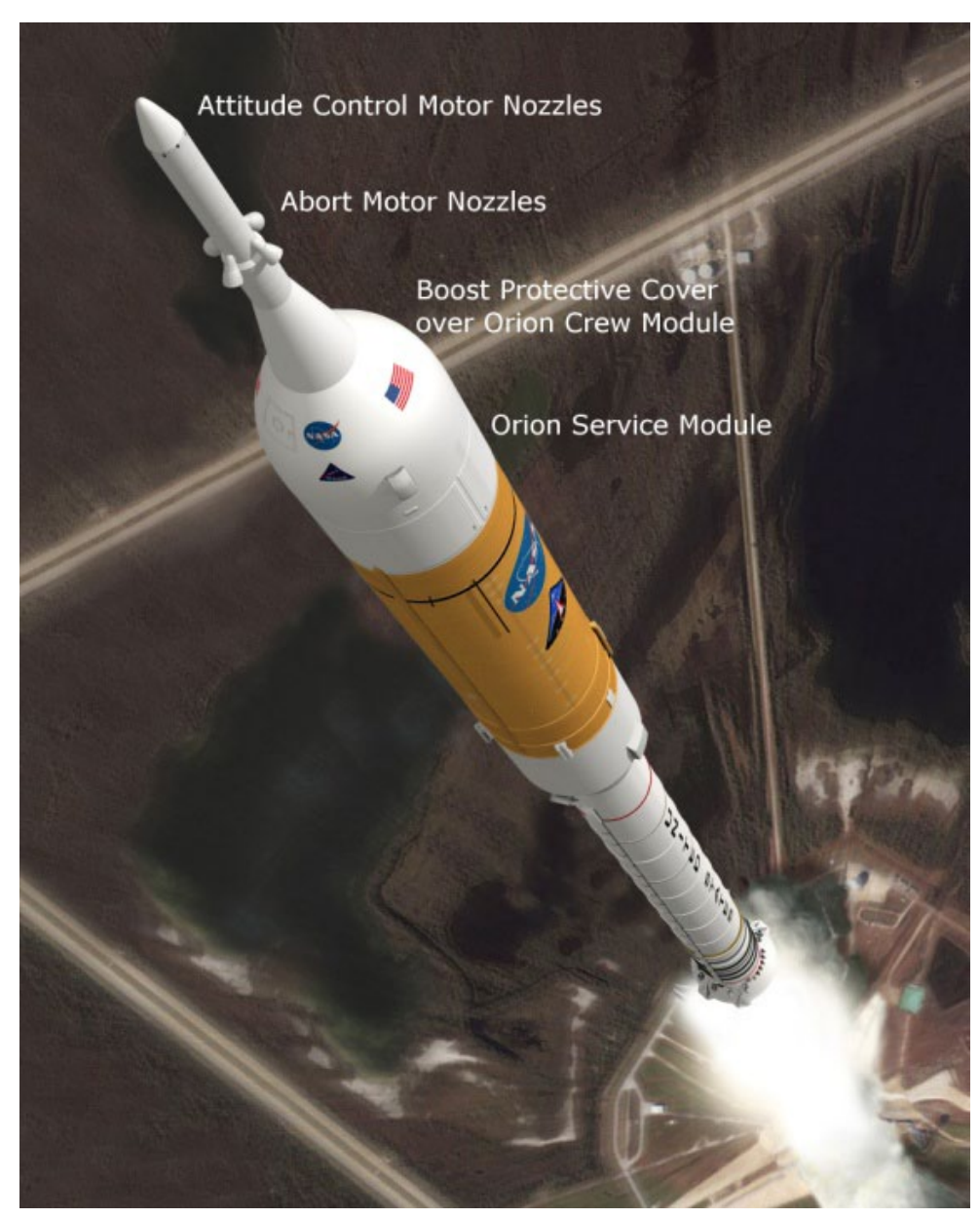

Figure 1.-Ares I during launch (artist's rendition).

\subsection{Background}

Accurate prediction of aerodynamic forces on the Ares I Launch Abort Vehicle (LAV) is important for determining the forces on the Orion crew and the trajectory of the vehicle. This report describes an experiment to improve the computational fluid dynamics (CFD) prediction capability for this type of problem.

The Ares I vehicle (Figure 1) is designed to deliver the Orion Crew Exploration Vehicle (CEV) to low-earth orbit. A launch abort system provides a means to quickly remove Orion from danger in the event of an emergency. The LAV consists of a tower and the Orion Crew Module but excludes the Orion Service Module. The tower includes an attitude control motor with eight nozzles, a solid-rocket Abort Motor (AM) with four nozzles, and a boost protective cover.

CFD predictions have raised questions about the most appropriate turbulence model for such flows. A simulation by researchers at NASA Ames Research Center of the LAV 606-068 configuration was run at an angle of attack of $20^{\circ}$, and a flight Mach number of 0.3 with the abort motors firing at 100 percent power. All cases were run with the OVERFLOW code (Ref. 1). Three turbulence models were used: Lag (Ref. 2), SST (Refs. 3 and 4), and Baldwin-Barth (Ref. 5). The cases run and their resulting axial force coefficients $\left(\mathrm{C}_{\mathrm{x}}\right)$ are summarized in Table 1 . 
TABLE 1.-CFD PREDICTIONS

\begin{tabular}{|l|l|c|}
\hline \multicolumn{1}{|c|}{ Code version } & $\begin{array}{c}\text { Turbulence } \\
\text { model }\end{array}$ & $\mathrm{C}_{\mathrm{x}}$ \\
\hline OVERFLOW 2.0aa "Lag_Robusta" & $\mathrm{Lag}$ & 1.8 \\
\hline OVERFLOW 2.0aa & SST & 0.8 \\
\hline OVERFLOW 2.0aa "Lag_Robusta" & SST & 0.7 \\
\hline OVERFLOW 2.0aa & Baldwin-Barth & 0.6 \\
\hline
\end{tabular}

The difference between the two SST results is probably due to the difference in the turbulent kinetic energy (TKE) production term, which is based on vorticity in the standard code and the strain rate in the Lag version. The large difference between the results from Lag turbulence model compared to those of other turbulence models raised questions about the accuracy of the predictions. Further investigation revealed that the mechanism for the higher force appears to be elevated turbulence transport in the shear layer of the AM plumes, resulting in energy transfer into the freestream which flows past the plumes and impinges on the LAV capsule. The mechanisms leading to elevated drag were dependent on jet temperature and hence velocity, for the fixed Mach number jet. These physical mechanisms were not implausible, and this raised the concern that jet temperature was an important parameter of the problem. Furthermore, all wind tunnel tests of LAV aerodynamics are run with jet plumes that are substantially cooler than the flight vehicles, because hot jets are very difficult to create and work with in wind tunnels.

An experiment was needed to determine a "right answer" for this problem. Salient features of the experiment included: 1) a freestream flow, 2) a high-energy jet at an angle to the freestream, 3) a capsulelike shape on which pressures could be recorded, and 4) a means for measuring detailed flow field characteristics of the plume and surrounding air. The AeroAcoustic Propulsion Laboratory (AAPL) at NASA Glenn Research Center was chosen as the site of this experiment based on its suitability for SPIV measurements and its capability to produce a high energy plume. However, the facility is not capable of pressures and temperatures as great as in the AM, so CFD studies were performed which confirmed that an experiment in this facility would provide an appropriate analog.

In many respects, this is a classic jet in crossflow problem. However, the high pressure and temperature of the jet, the angle of the jet, and the presence of the Orion capsule are novel aspects not found in the existing literature.

\subsection{Equipment and Procedures}

The experiment was conducted in the AeroAcoustic Propulsion Laboratory (AAPL) at the NASA Glenn Research Center between July and October of 2008. The AAPL is an acoustic test facility housed in a $130 \mathrm{ft}$ diameter acoustically lined dome (Ref. 6). Three active test rigs are housed in the AAPL. For this experiment the Nozzle Aeroacoustic Test Rig (NATR) (Ref. 7) was used. The NATR is a 53-in. diameter freejet rig capable of freestream velocities up to 0.3 Mach number. Installed within the NATR is the High Flow Jet Exit Rig (HFJER), a jet engine simulator (Ref. 8). Figure 2 depicts the NATR and HFJER within the AAPL facility. 


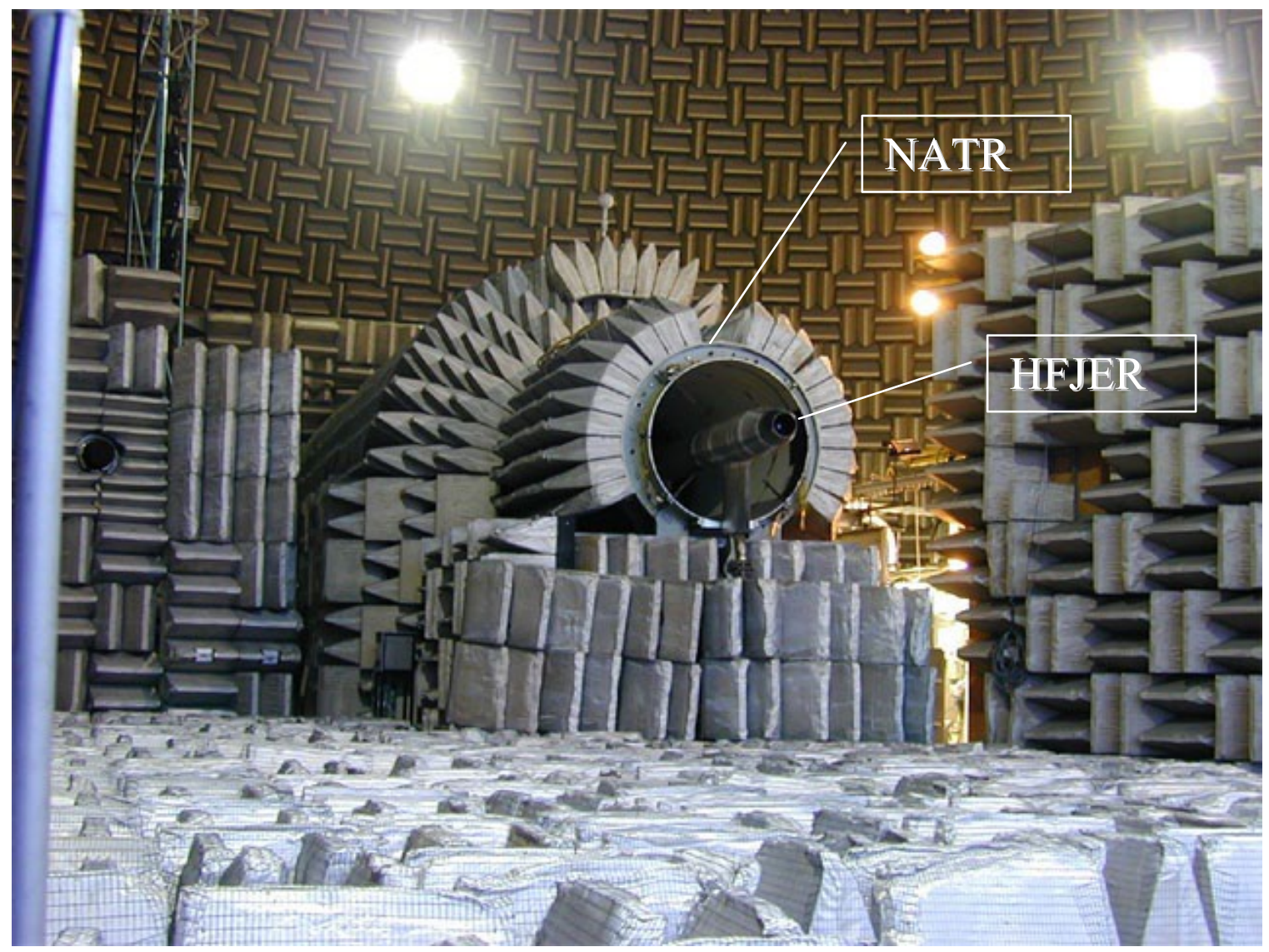

Figure 2.-Nozzle Aeroacoustic Test Rig (NATR) and High Flow Jet Exit Rig (HFJER).

Historically, the HFJER has supplied nozzles of 10 to $20 \mathrm{in}^{2}$ with heated flow at nozzle pressure ratios up to 4 and temperatures up to $1900 \mathrm{R}$ at a flow rate up to $29 \mathrm{lbm} / \mathrm{sec}$ in single flow configuration. For this test, the rig was modified to provide flow at a nozzle pressure ratio of 28.5 and temperature up to $1460 \mathrm{R}$ at a significantly lower flow rate of approximately $1 \mathrm{lbm} / \mathrm{sec}$. Cold air was supplied to the HFJER continuously at up to 450 PSIG. The air was heated using a natural gas combustor.

The Stereo Particle Image Velocimetry (SPIV) system enabled cross-stream measurements of the three-component velocity field from the test article. The SPIV system employed two high-resolution (4008x2672 pixel) cameras to provide a 600 - by $600-\mathrm{mm}$ field of view. The measurement plane was illuminated using a $400 \mathrm{~mJ} /$ pulse Nd:YAG laser system. The flow was seeded with alumina seed particles in the nozzle core flow, and a propylene glycol based liquid seed material was used in the ambient flow stream. The large field of view was required in order to be able to capture the angled nozzle plume over a range of 20+ diameters downstream from the nozzle exit plane. In addition to the cross-stream planes, the SPIV system was reconfigured on the final test day to acquire axial plane slices of the $25^{\circ}$ and $40^{\circ}$ nozzle flow. The field of view of the SPIV system was nominally the same for the axial plane measurements as that used in the cross-stream configuration. The SPIV image data were processed to yield velocity vector maps with $1 \mathrm{~mm}$ spatial resolution. A sequence of 400 velocity vector maps were acquired at each measurement station and ensemble averaged to provide first- and second-order statistics over the entire measurement plane. All of the processed SPIV data were placed in the nozzle coordinate system and transferred to NASA Ames for comparison to CFD. Wernet et al. (Ref. 9) describe the SPIV data collection and results in greater detail. CFD validation studies are occurring at NASA Ames Research Center, and will be reported by A. J. Shestopalov et al. at a future date. 


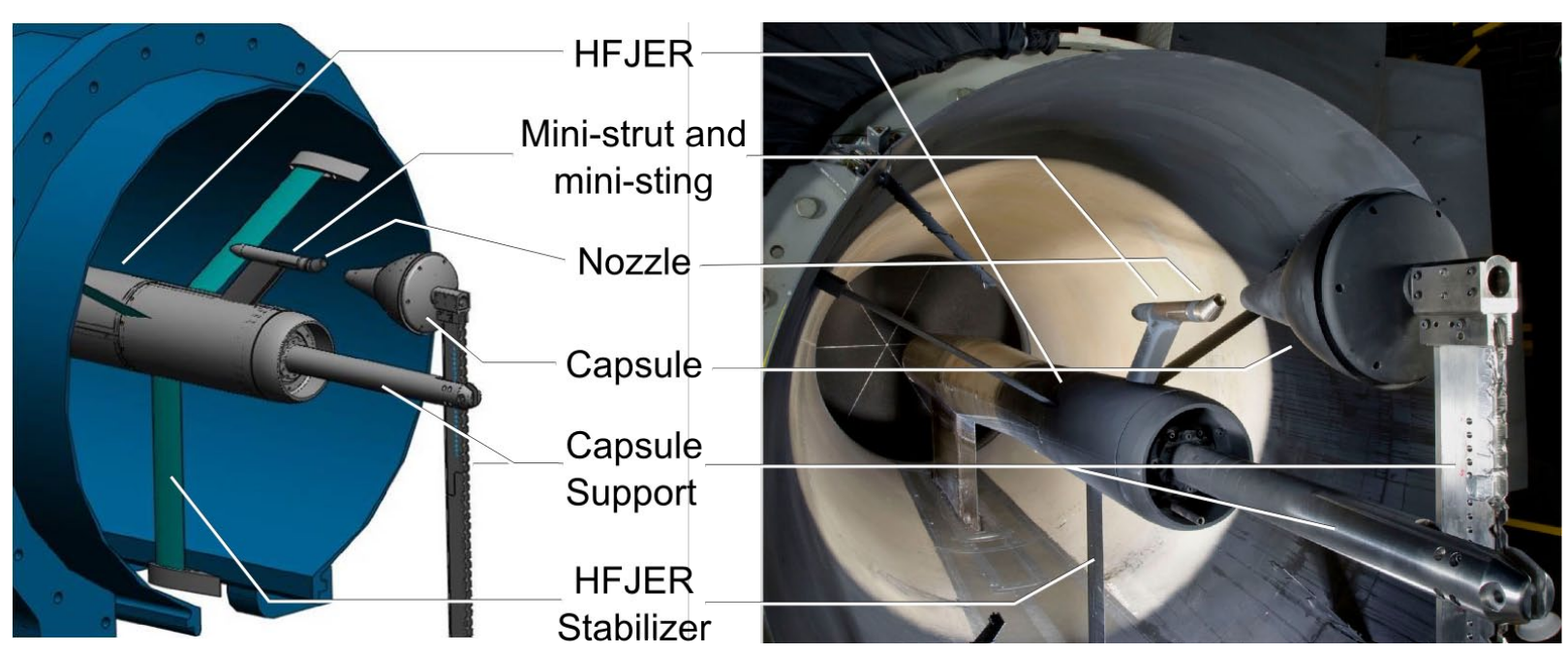

Figure 3.-85-AA Model in the NATR.

As described earlier, the problem to be modeled featured a hot, high-speed jet issuing at an angle relative to a freestream flow. The jet traveled past a capsule shape, not striking the capsule, but passing close enough that freestream flow striking the capsule interacted with the jet shear layer before reaching the capsule.

Figure 3 shows an illustration and photograph of the model configuration. The end of the HFJER was capped and an extension from this cap served as a support for the capsule. A "mini-strut" and "ministing" were attached to the HFJER sting, to supply heated air to the nozzle. Three interchangeable nozzles were built, to vector the jet $0^{\circ}, 25^{\circ}$, and $40^{\circ}$ from the freejet axis. Figure 4 shows details of the nozzles' internal flowpaths. Design exit Mach number of the nozzles was 2.78, and design NPR was 26.3. Nozzle instrumentation comprised a static pressure tap and a thermocouple upstream of the nozzle throat.

A support strut extended from the base of the HFJER to support the capsule model. The design of the support strut allowed for the repositioning of the capsule as needed. Two sets of bolt holes at the connection between the capsule and the support strut allowed the capsule to be mounted with its axis at $0^{\circ}$ (for the $25^{\circ}$ nozzle) and $15^{\circ}$ (for the $40^{\circ}$ nozzle) relative to the freejet axis. Thus, the capsule rotates with the nozzle in these cases. These rotational positions represent the vehicle at different angles of attack. A series of 21 bolt holes in the vertical support strut allowed the capsule's vertical position to be adjusted in $1 / 2$ in. increments. Capsule position was designated by a number from 1 (lowest position) to 19 (highest position). Figure 5 shows the capsule positions used during this experiment. The red portions of the figure represent the $25^{\circ}$ vectored nozzle and the capsule mounted with $0^{\circ}$ angle of attack in either position 10 or 11. The blue portions of the figure represent the $40^{\circ}$ vectored nozzle and the capsule mounted with $15^{\circ}$ angle of attack in either position 18 or 19. The axial position and angle of the capsule relative to the nozzle in these configurations were representative of the Ares I configuration; the vertical position was not. Instead, the vertical position was adjusted to match the capsule surface pressure characteristics observed in the original CFD problem, as described in Section 3.2. 

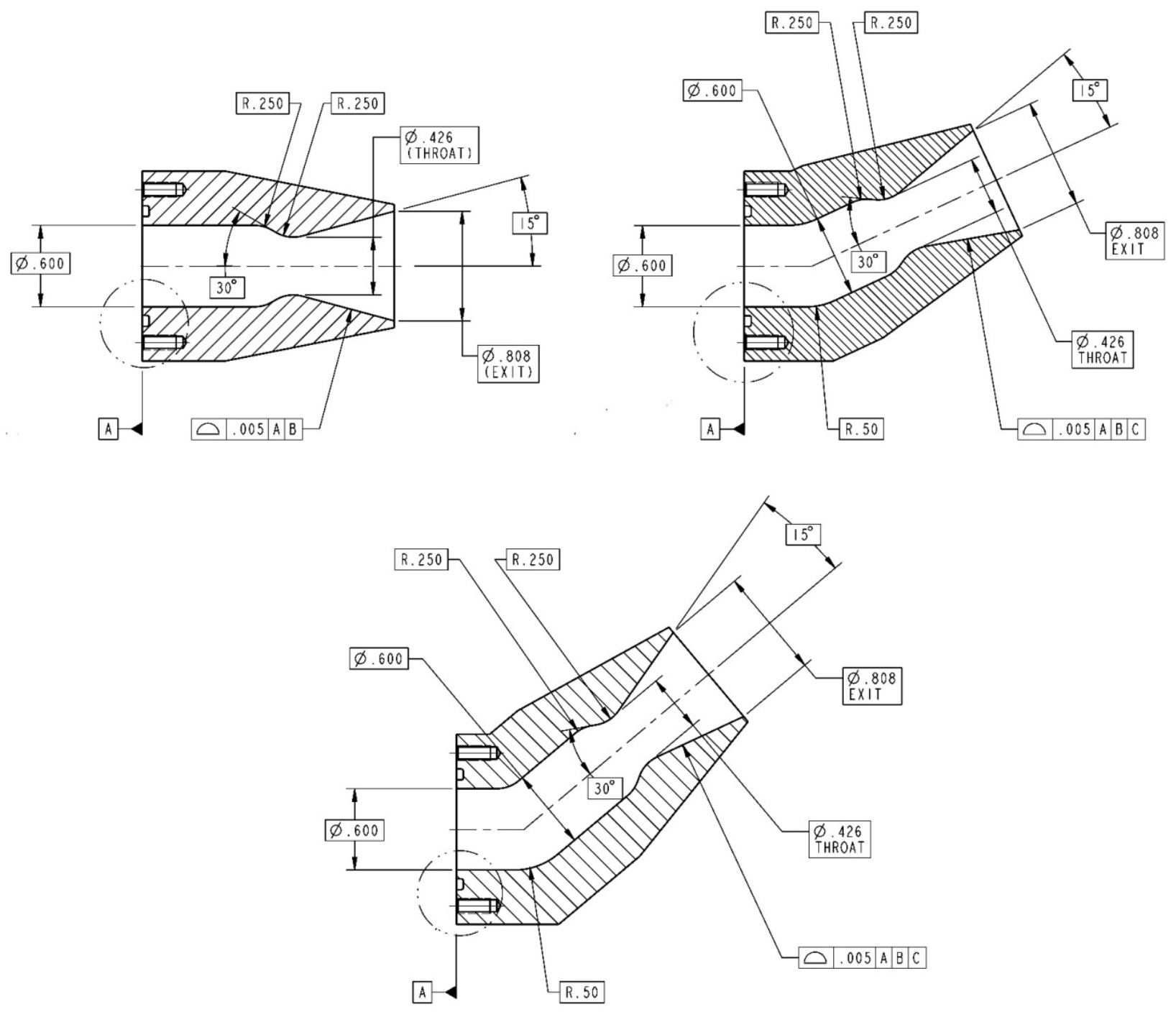

Figure 4.-Geometric details for $0^{\circ}, 25^{\circ}$, and $40^{\circ}$ nozzles.

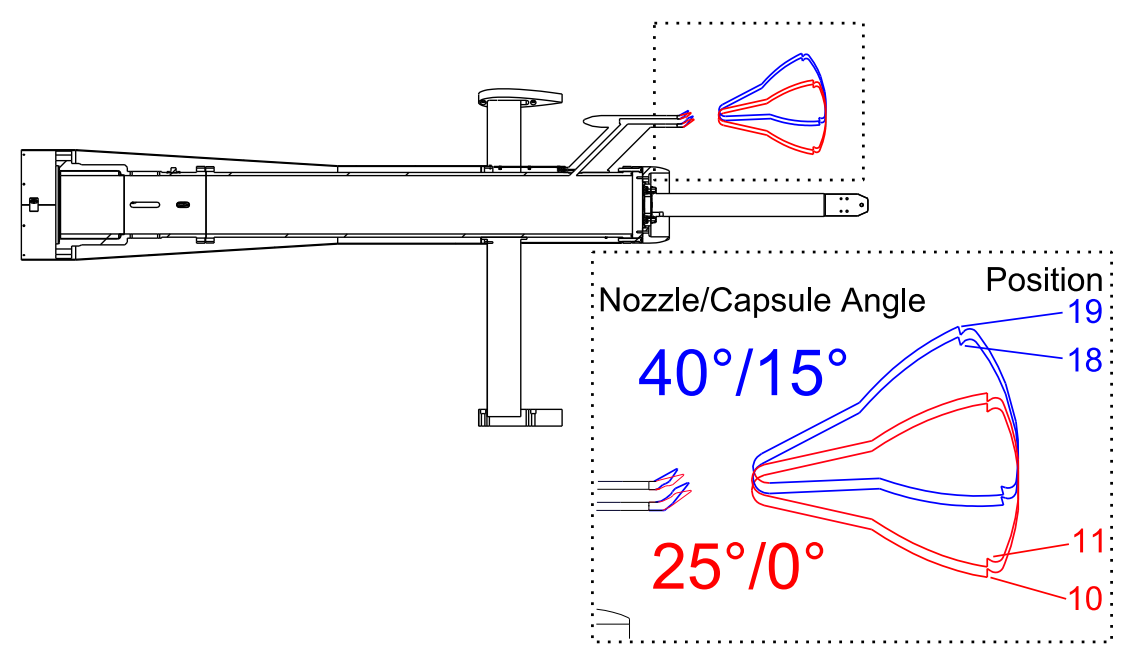

Figure 5.-Capsule positions. 


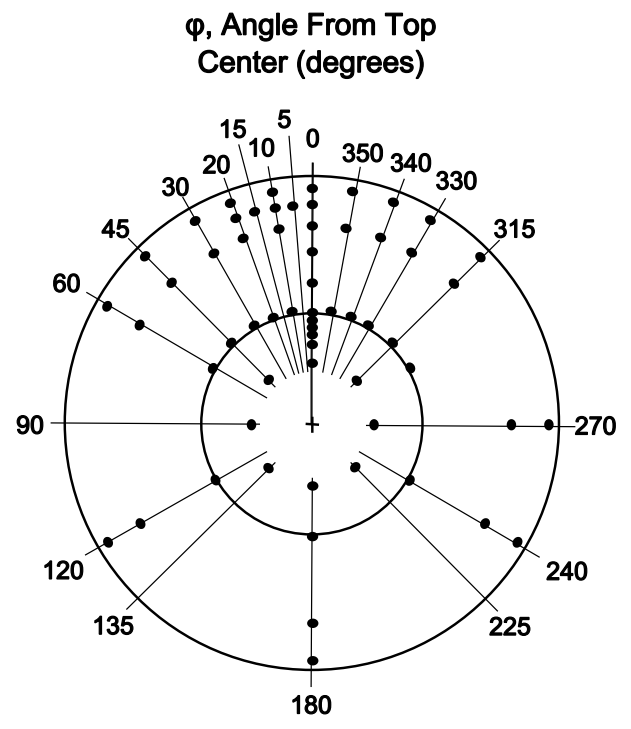

Front View

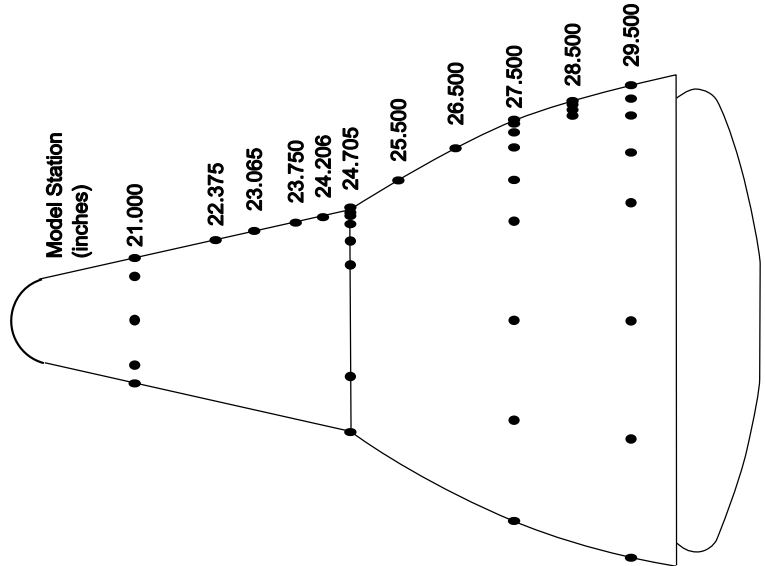

Side View

Figure 6.-Capsule tap locations.

The capsule was a 4 percent scale model of the LAV without the umbilical cutout or the tower. A total of 63 static pressure taps were arranged on the capsule surface as shown in Figure 6.

For each configuration, the HFJER was operated long enough to reach thermal equilibrium, and then SPIV data were acquired. Steady-state data, such as test conditions and capsule pressures, were sampled over a one second period. A plane of SPIV data required approximately two minutes of sampling to obtain a valid statistical population. A recording of the steady-state data was taken for each plane of SPIV data recorded. During operations, the primary test conditions (NPR, jet temperature, freejet Mach number) were held to no more than 0.5 percent root mean square error from the desired test condition.

For the configurations with the capsule present, data was acquired in a two-step process. First, the model was run using cold air, and capsule pressures were recorded for several vertical positions of the capsule. From these runs a capsule position was selected for a run using heated air. The capsule position was selected based on evidence of impingement of vortical structures in the plume wake on the capsule, as observed in the CFD studies. For details of this selection process, see Section 3.2.

A total of 8 configurations were tested, as shown in Table 2. The test matrix included all of the available nozzles, with various SPIV configurations to capture different parts of the flow. Configurations with the capsule absent were intended to provide a baseline case with which to compare the configurations with the capsule present. In addition, configurations with the capsule absent served as a hedge against the possibility that laser flare off of the capsule would greatly reduce the quality of the SPIV data for configurations with the capsule present. Fortunately, this was not observed in this experiment.

TABLE 2.-CONFIGURATIONS TESTED

\begin{tabular}{|l|c|l|l|}
\hline $\begin{array}{c}\text { Configuration } \\
\text { name }\end{array}$ & $\begin{array}{c}\text { Nozzle } \\
\text { angle }\end{array}$ & $\begin{array}{c}\text { Capsule } \\
\text { present? }\end{array}$ & \multicolumn{1}{|c|}{ SPIV configuration } \\
\hline Cancun & 0 & No & Cross-stream \\
\hline Bahamas & 25 & No & Cross-stream \\
\hline Cozumel & 25 & No & Cross-stream, small field of view \\
\hline Vail & 25 & No & Streamwise \\
\hline Galapagos & 25 & Yes & Cross-stream \\
\hline Puerto Vallarta & 40 & No & Cross-stream \\
\hline Vegas & 40 & No & Streamwise \\
\hline Rio de Janeiro & 40 & Yes & Cross-stream \\
\hline
\end{tabular}




\subsection{Results}

\subsection{SPIV Measurements}

Figure 7 and Figure 8 show velocity contours for the $25^{\circ}$ and $40^{\circ}$ nozzles, respectively, as viewed from the side. The SPIV measurement process and results from this experiment are more thoroughly discussed in a separate paper (Ref. 8). That paper also compares SPIV results to CFD of the experiment using the SST turbulence model with and without a compressibility correction. It concludes that neither CFD solution matches the SPIV data in all details (e.g., shock spacing, cross-stream vorticity, plume dispersion), with the SPIV data generally falling between the CFD solutions with and without compressibility correction.

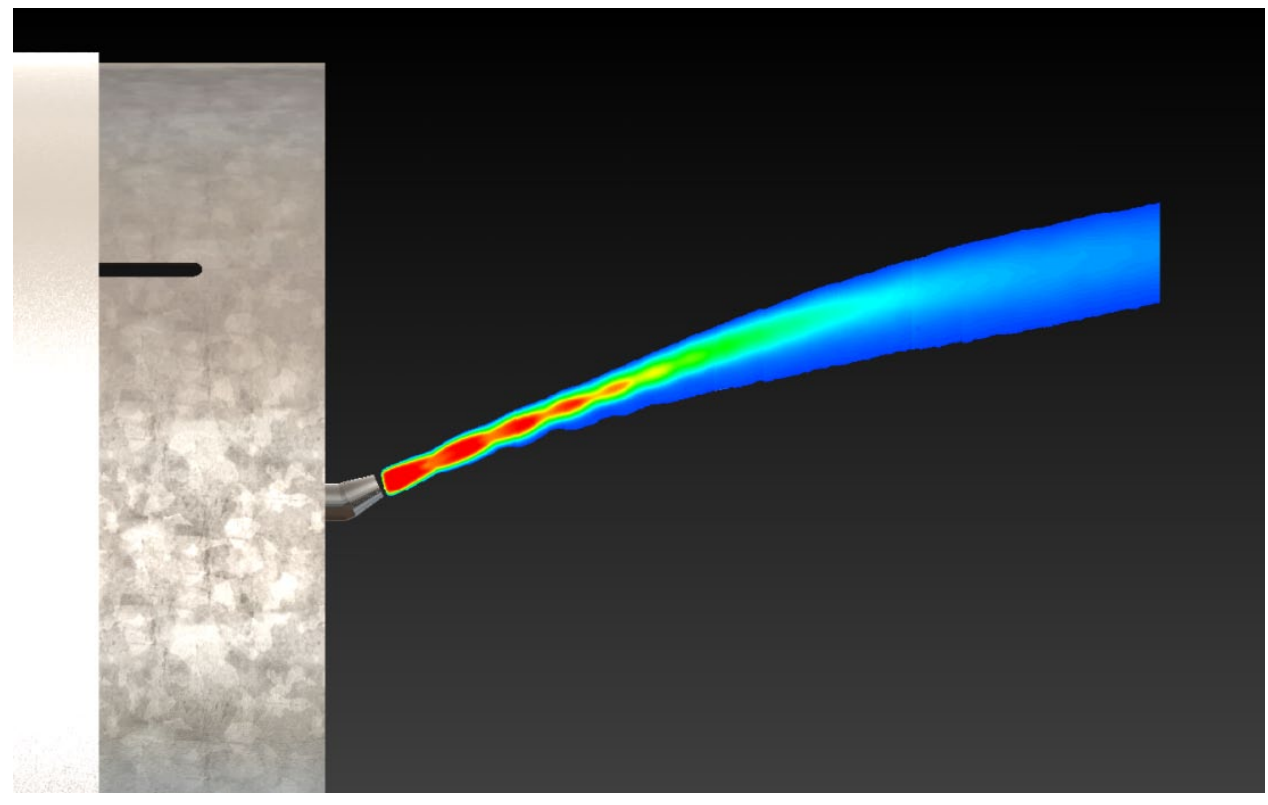

Figure 7.-Velocity contours for $25^{\circ}$ nozzle, NPR=28.5, $\mathrm{T}=1350 \mathrm{R}$.

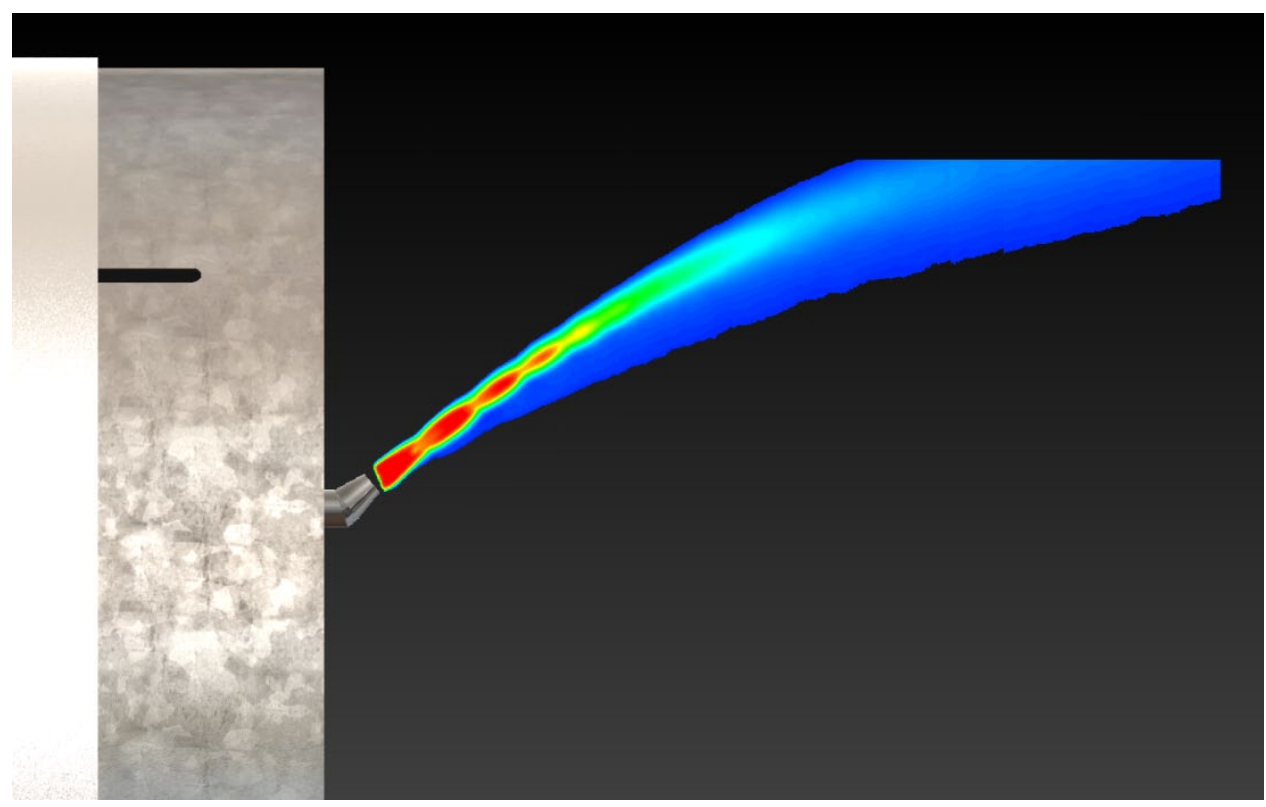

Figure 8. -Velocity contours for $40^{\circ}$ nozzle, NPR=28.5, $\mathrm{T}=1350 \mathrm{R}$. 
Figure 9 through Figure 14 show velocity results from the SPIV axial measurements. In these figures, axial location is normalized by the nozzle exit diameter. Note that "axial" in this context refers to planes normal to the freejet axis, not the jet axis. Figure 9 shows velocities for the $0^{\circ}$ nozzle. Axial locations normalized by the nozzle diameter in the figure are: (top row) $0.55,1.43,2.31,4.06$, (middle row) 5.83 , 7.59, 9.79, 12.97, (bottom row) 17.37, 23.53, 32.00.

Figure 10 shows velocity contours for the $25^{\circ}$ nozzle. Normalized axial locations in the figure are: (top row) 0.76, 2.35, 3.95, 5.54, (middle row), 7.14, 9.19, 12.04, 16.03, (bottom row) 21.55, 29.26.

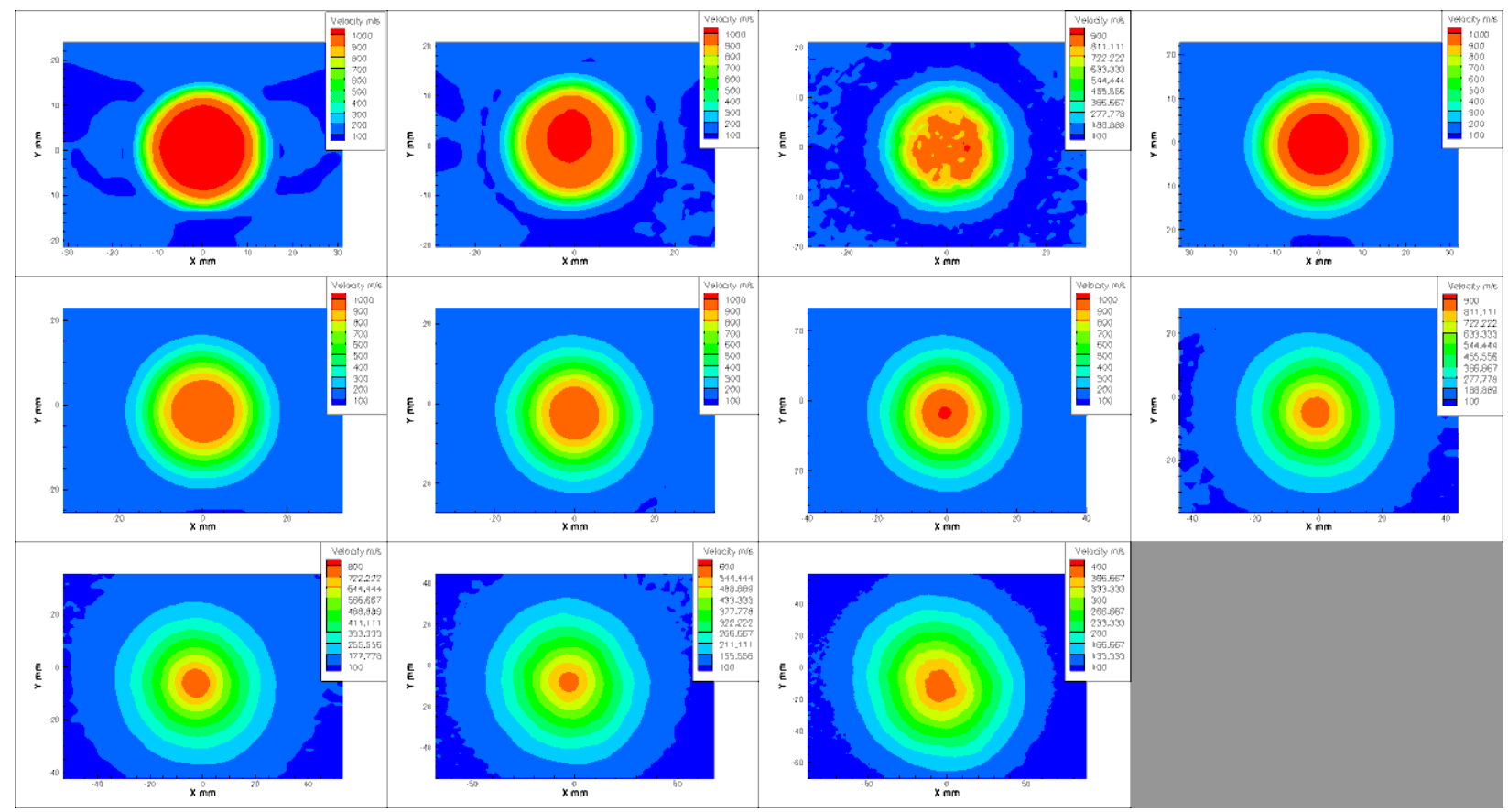

Figure 9.-Velocity contours for $0^{\circ}$ nozzle, no capsule, NPR=28.5, T=1350 R.

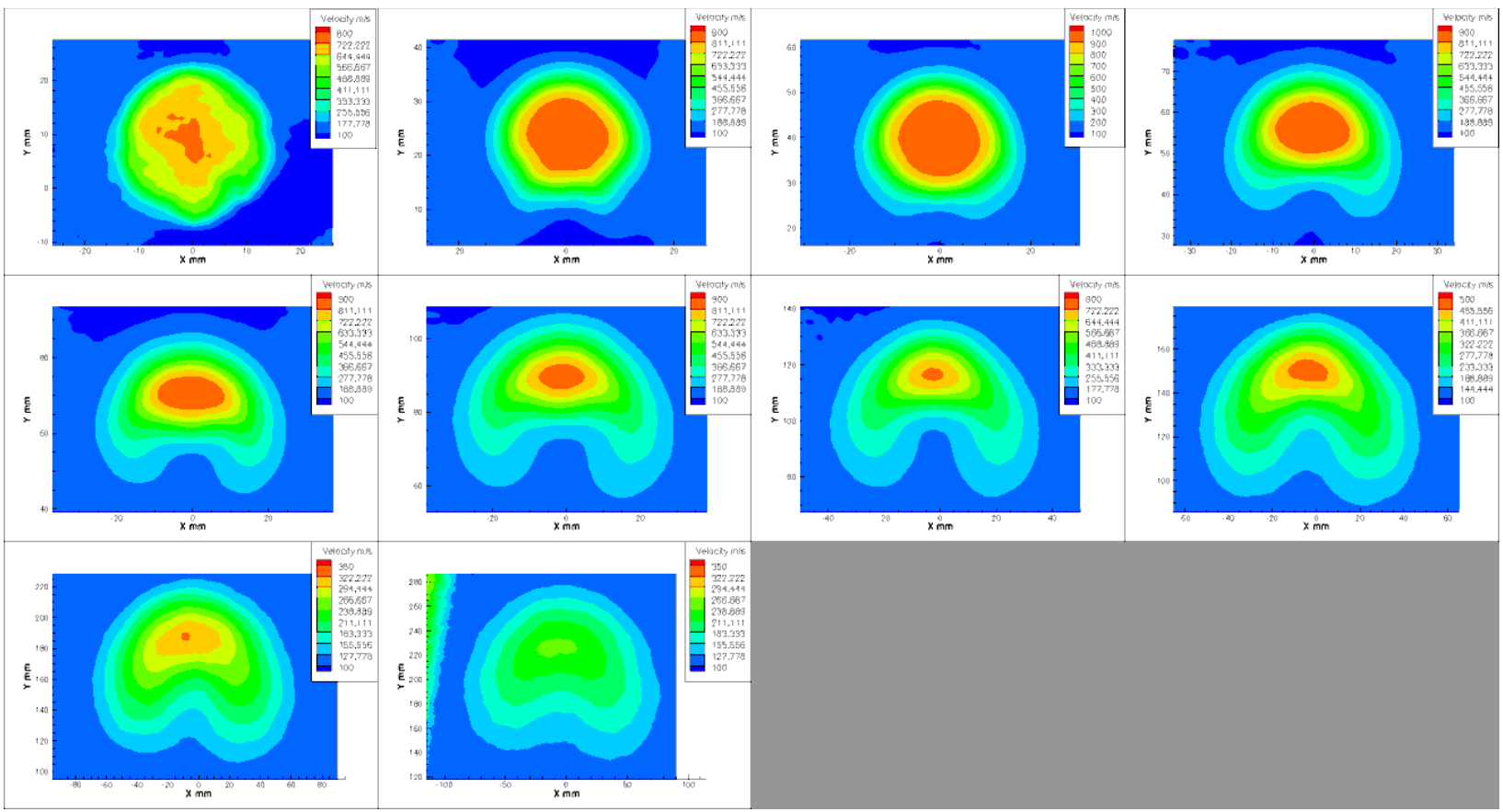

Figure $10 .-$ Velocity contours for $25^{\circ}$ nozzle, no capsule, NPR=28.5, T=1260 R 
Figure 11 and Figure 12 show velocity contours for the $40^{\circ}$ nozzle at two different temperatures. Normalized axial locations in Figure 11 are: (top row) 0.87, 1.53, 2.22, 3.56, (middle row) 4.91, 6.26, 7.98, 10.40, (bottom row) 13.77, 24.95. Normalized axial locations in Figure 12 are: (top row) 0.87, 1.53, $2.19,2.85$, (middle row) $3.51,4.17,4.83,5.60$, (bottom row) $6.28,7.03$.

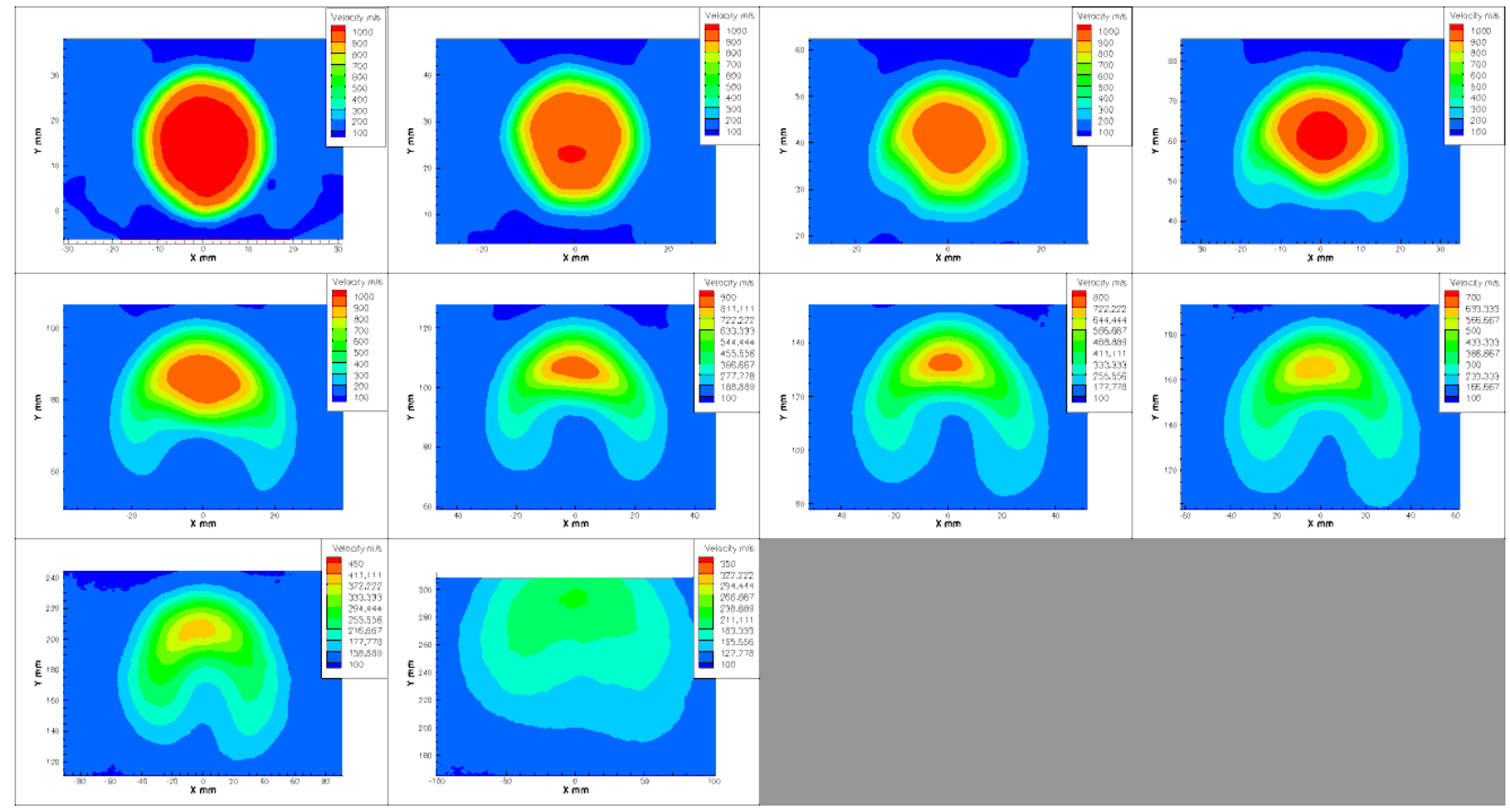

Figure 11.-Velocity contours for $40^{\circ}$ nozzle, no capsule, NPR=28.5, $T=1350 \mathrm{R}$.

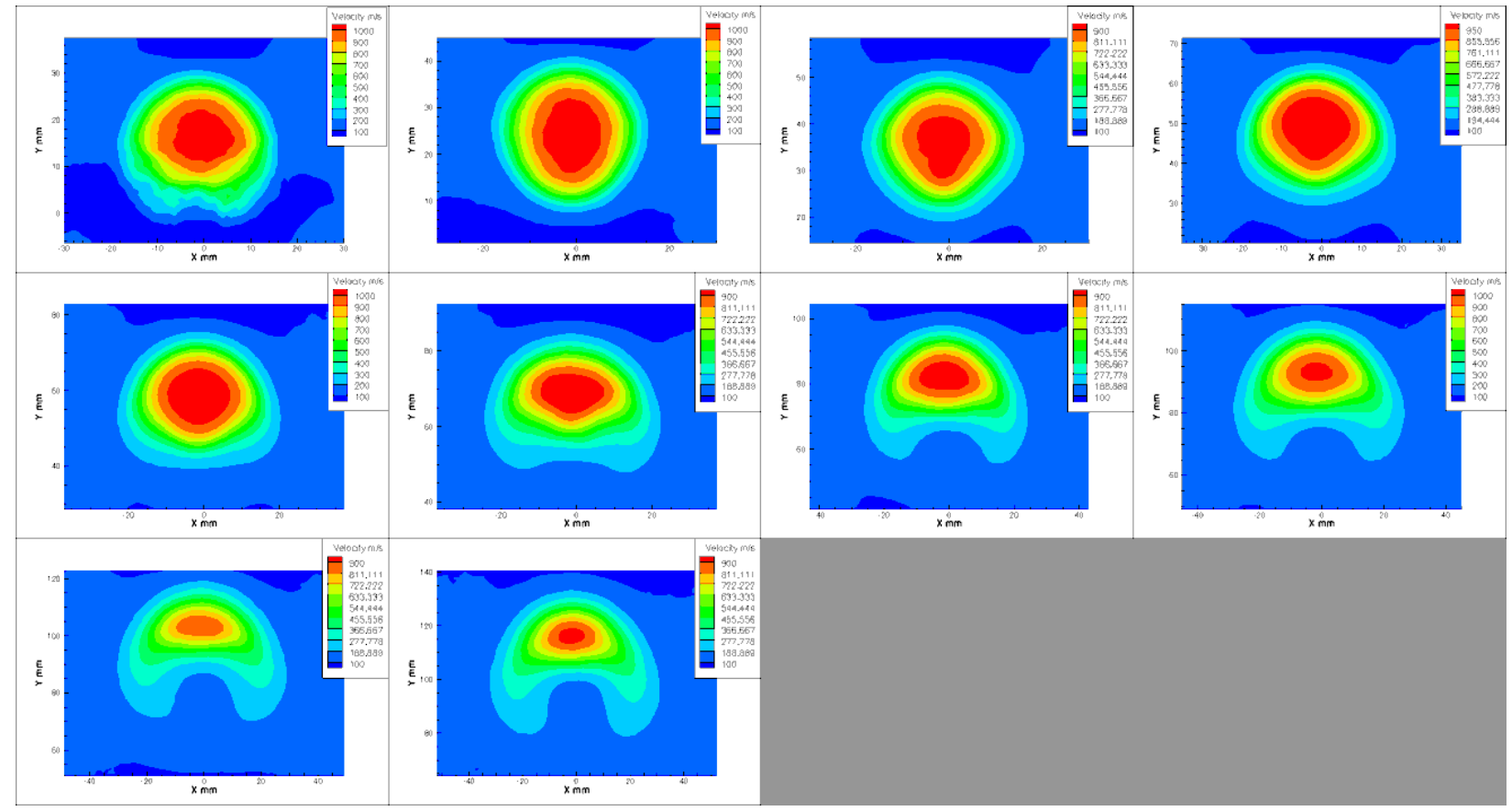

Figure 12.-Velocity contours for $40^{\circ}$ nozzle, no capsule, NPR=28.5, T=1460 R. 
Figure 13 shows velocity contours for the $25^{\circ}$ nozzle. Normalized axial locations in the figure are: (top row) $0.76,2.35,3.95,5.54$, (middle row) 7.14, 9.12, 11.98, 13.84, (bottom row) 15.93, 18.46, 21.54, 29.24.

Figure 14 shows velocity contours for the $25^{\circ}$ nozzle. Normalized axial locations in the figure are: (top row) $0.87,2.19,3.56,4.91$, (bottom row) $6.16,8.00,10.40,13.74$.

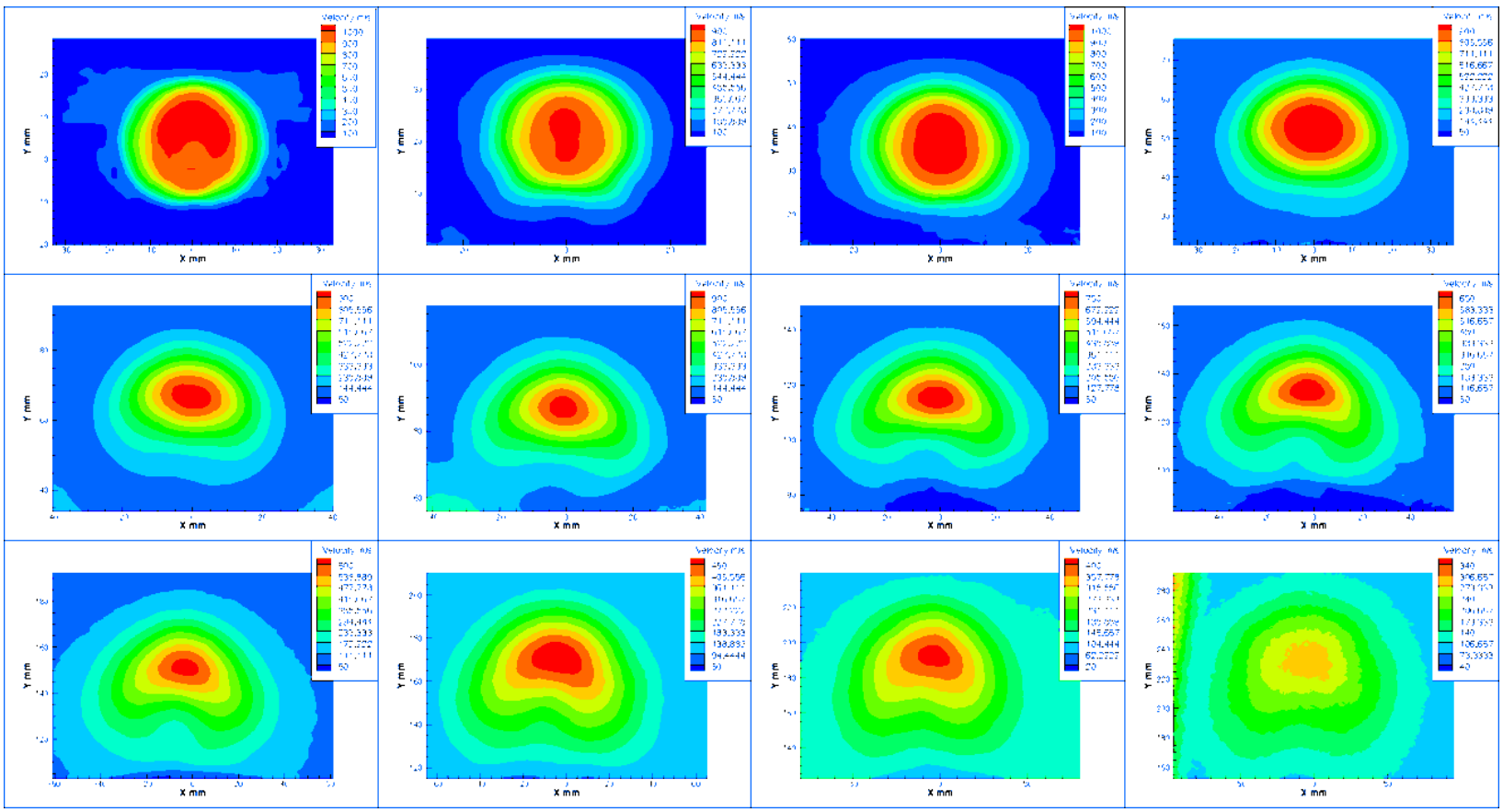

Figure 13.-Velocity contours for $25^{\circ}$ nozzle with capsule, NPR=28.5, $T=1350 \mathrm{R}$.

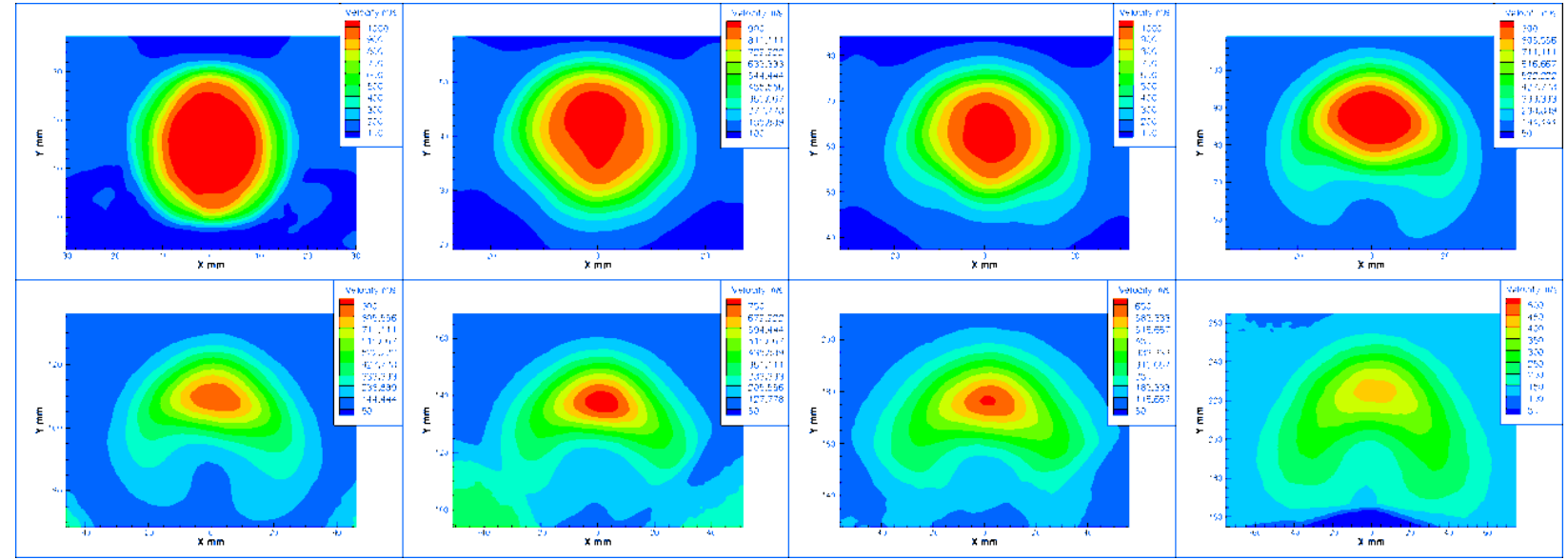

Figure 14.-Velocity contours for $40^{\circ}$ nozzle with capsule, NPR=28.5, $\mathrm{T}=1350 \mathrm{R}$. 


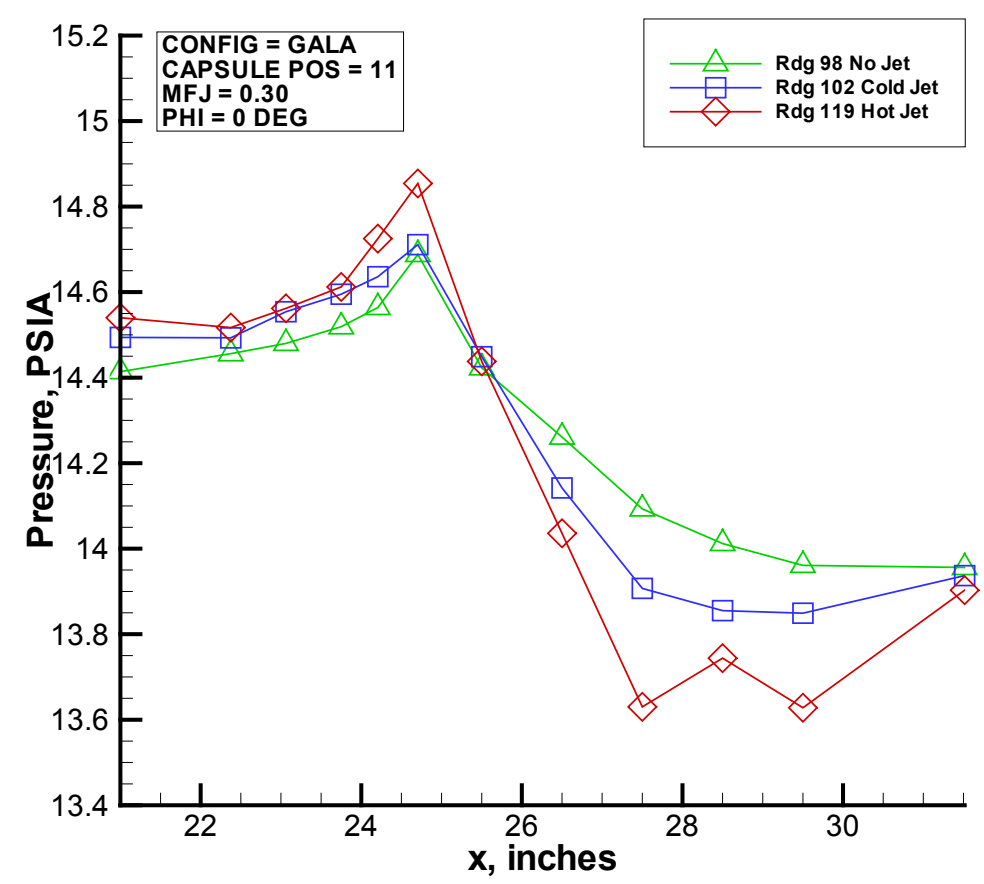

Figure 15.-Capsule pressures, $25^{\circ}$ nozzle at three jet conditions.

\subsection{Capsule Pressures}

Figure 15 through Figure 22 depict measured capsule surface pressures for the configurations in which the capsule was present.

Figure 15 shows capsule surface pressures for the $25^{\circ}$ nozzle at three jet conditions: off, cold, and hot. Pressures are from the row of pressure taps closest to the jet (the $\varphi=0^{\circ}$ position in Figure 6 ). The pressures rise from the nose of the capsule until the break at $x=24.7 \mathrm{in}$., then decrease as the flow accelerates around the bulk of the capsule. This behavior is reflected in all of the configurations where the capsule was present. This effect is enhanced in the cold jet as compared to jet off, and in the hot jet as compared to the cold jet. The enhancement is likely due to the entrainment of freestream flow by the jet flow.

Figure 16 through Figure 23 show capsule pressures at various positions and flow conditions. Refer to Figure 5 for capsule positions. In these pressure plots, the pressures are plotted by axial station. For Figure 16 through Figure 18 and Figure 20 through Figure 22, axial stations are denoted by color, with the image of the capsule to the right denoting the location of each station.

Figure 16 and Figure 17 show capsule pressures for cold flow for the $25^{\circ}$ nozzle configuration at capsule positions 10 and 11 respectively. While the two figures are similar, the position 11 plot shows a much deeper "dip" in pressure at the $x=27.5 \mathrm{in}$. position. This dip is caused by vorticity from the interaction of the plume with the freestream. This dip was observed in the original CFD predictions and was considered an indicator that flow conditions were similar to those in the original CFD. Observations of the plume indicated that moving the capsule to position 12 would cause the jet to impinge directly on the capsule, which was not desired. Therefore, position 11 was chosen for hot flow studies.

Figure 18 shows capsule pressures for heated flow through the $25^{\circ}$ nozzle with the capsule at position 11. Figure 19 shows the data in Figure 17 and Figure 18 compared. The dip in the hot case is more pronounced for $\mathrm{x}=27.5 \mathrm{in}$. and aft, suggesting stronger vorticity.

Figure 20 and Figure 21 show capsule pressures for cold flow through the $40^{\circ}$ nozzle with the capsule at positions 19 and 18, respectively. The differences between these two plots are much more subtle than in previous comparisons. Again the plume would impinge on the capsule at the next position, so position 18 was chosen for hot flow. 
Figure 22 depicts capsule pressures for heated flow through the $40^{\circ}$ nozzle with the capsule at position 18. Figure 23 shows the data in Figure 21 and Figure 22 compared. Here, the difference between hot and cold flow is less pronounced than in the $25^{\circ}$ case.

\section{Capsule Surface Pressures}

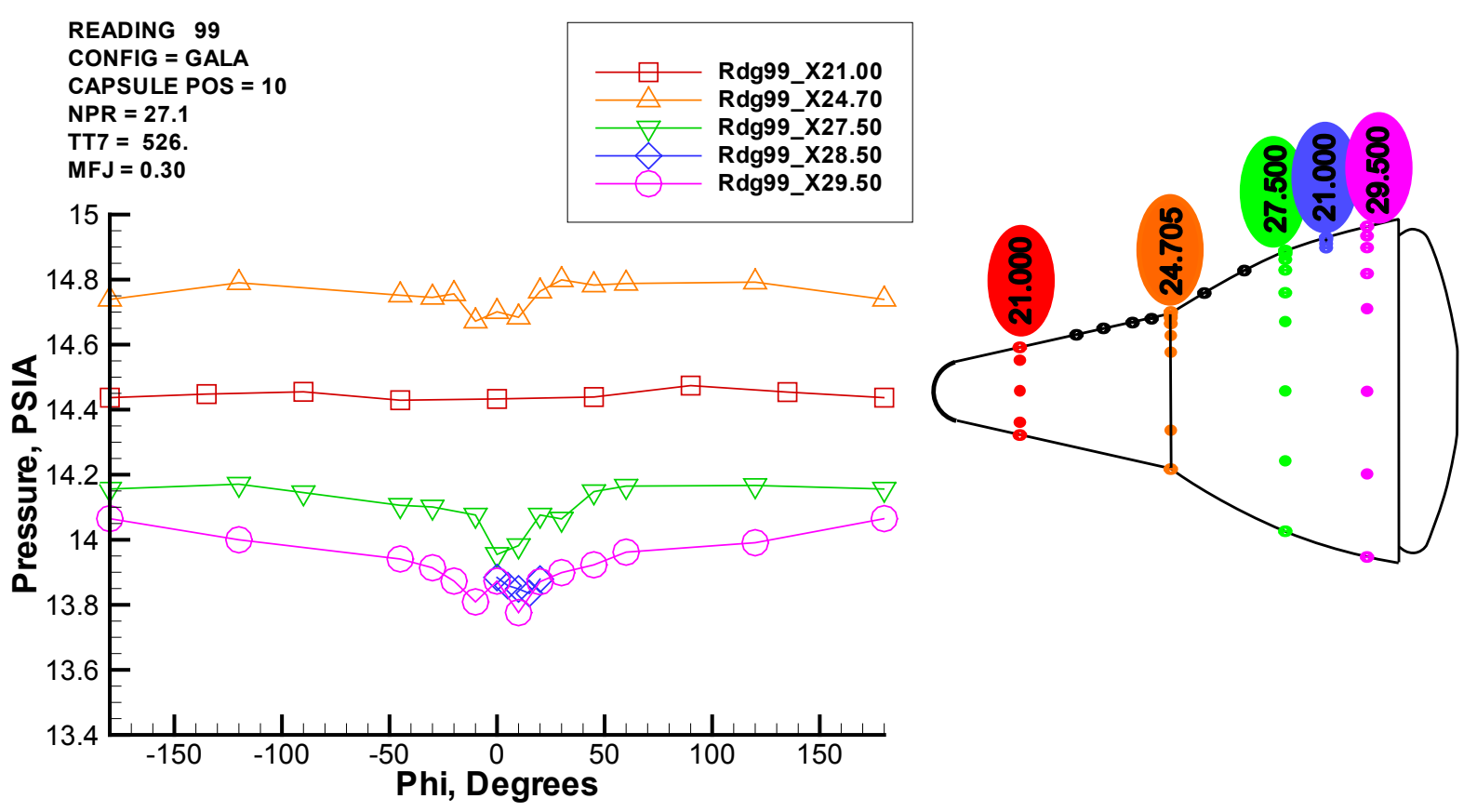

Figure 16.-Capsule pressures for $25^{\circ}$ nozzle, position 10 , cold.

\section{Capsule Surface Pressures}

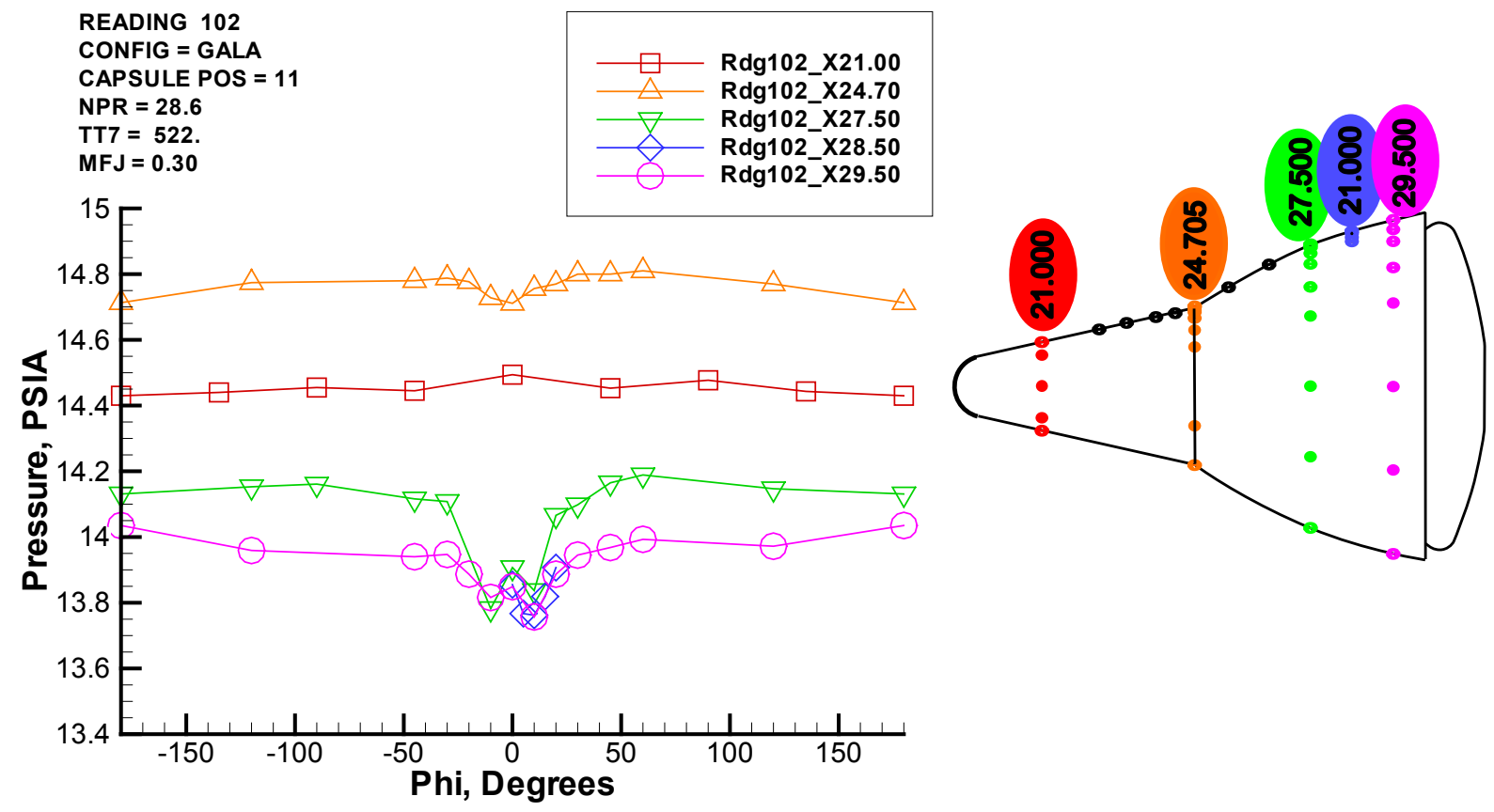

Figure 17.-Capsule pressures for $25^{\circ}$ nozzle, position 11 , cold. 


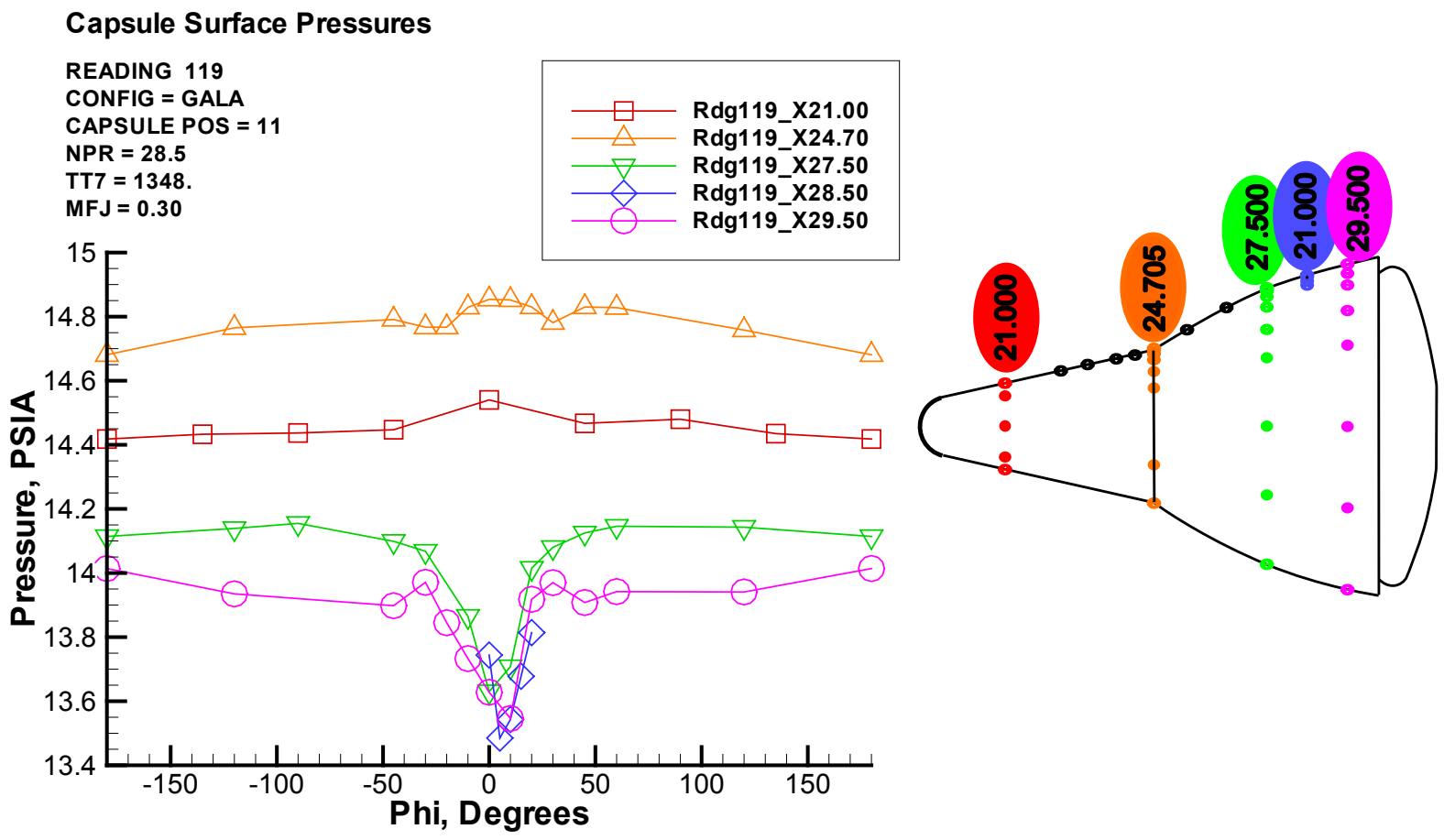

Figure 18.-Capsule pressures for $25^{\circ}$ nozzle, position 11 , hot.

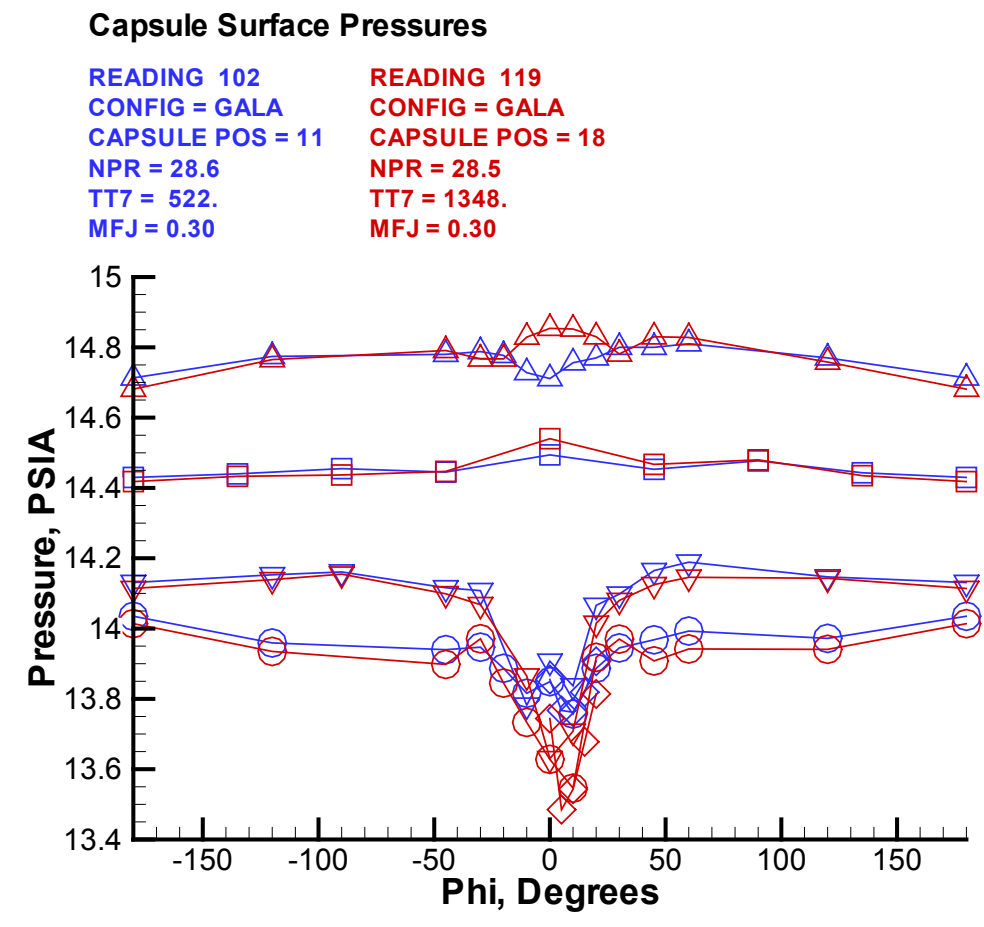

Figure 19.-Capsule pressures for $25^{\circ}$ nozzle, position 11 , cold and hot compared. 


\section{Capsule Surface Pressures}

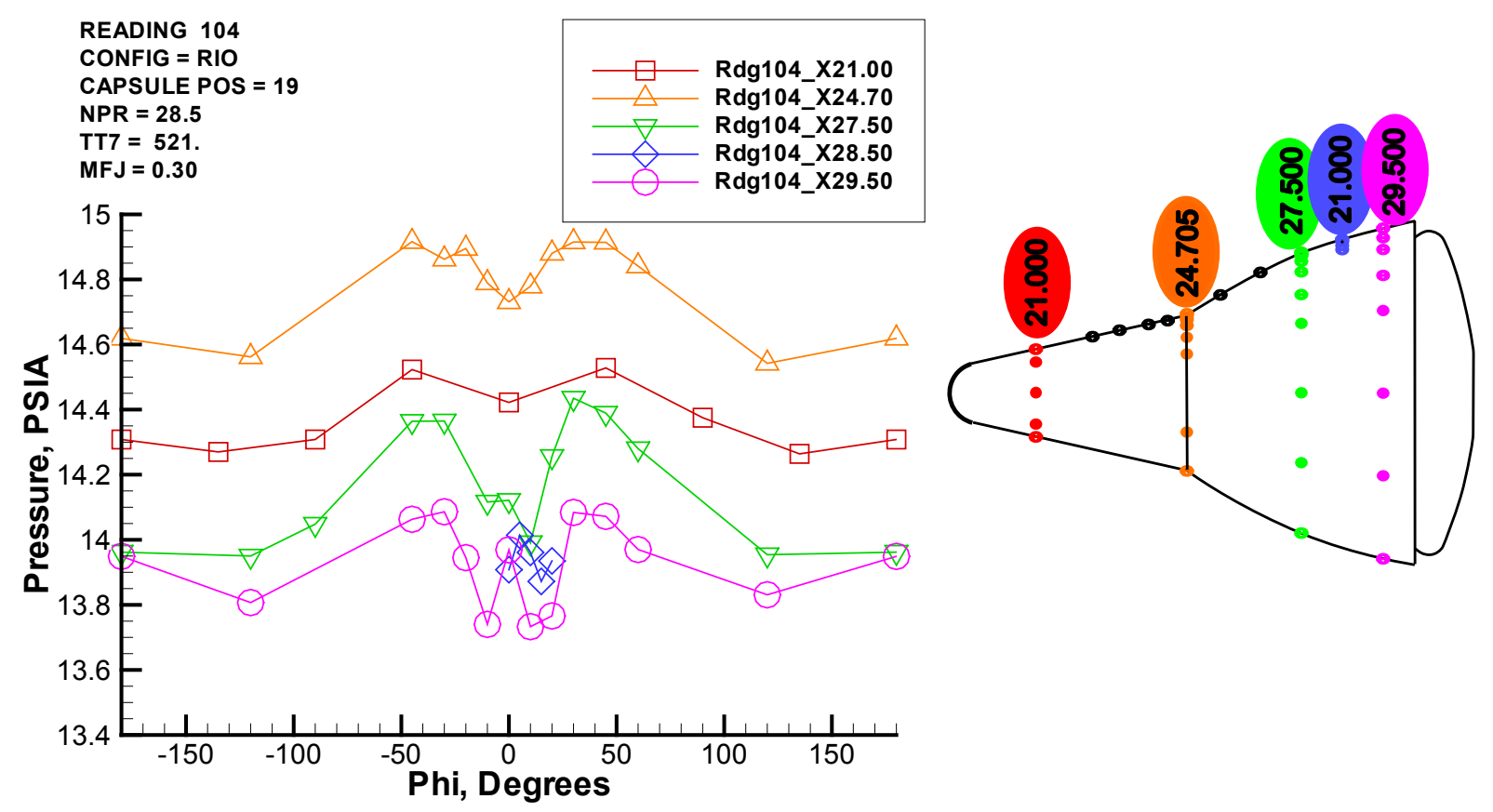

Figure 20.-Capsule pressures, $40^{\circ}$ nozzle, position 19 , cold.

\section{Capsule Surface Pressures}

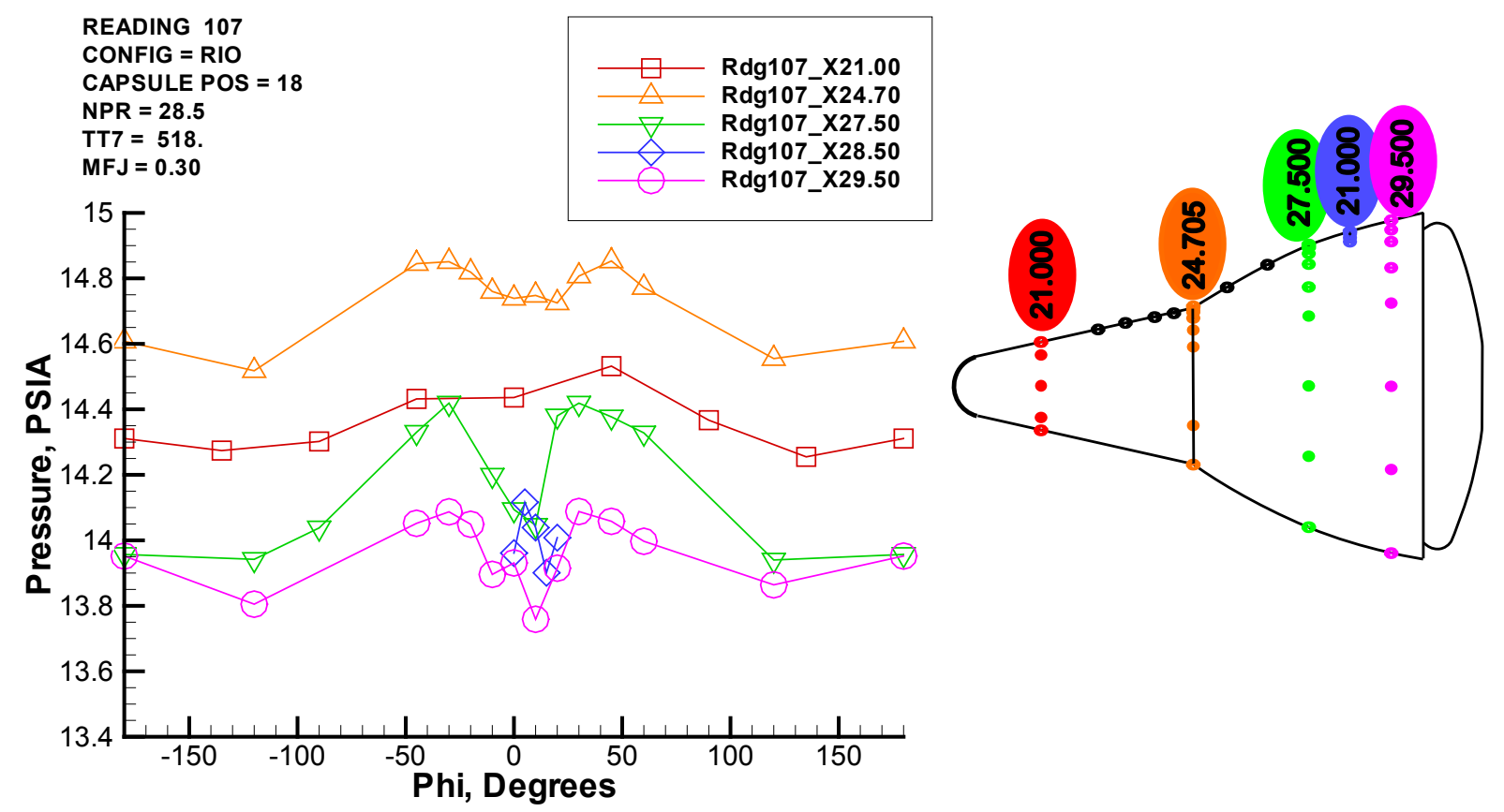

Figure 21.-Capsule pressures, $40^{\circ}$ nozzle, position 18 , cold. 


\section{Capsule Surface Pressures}

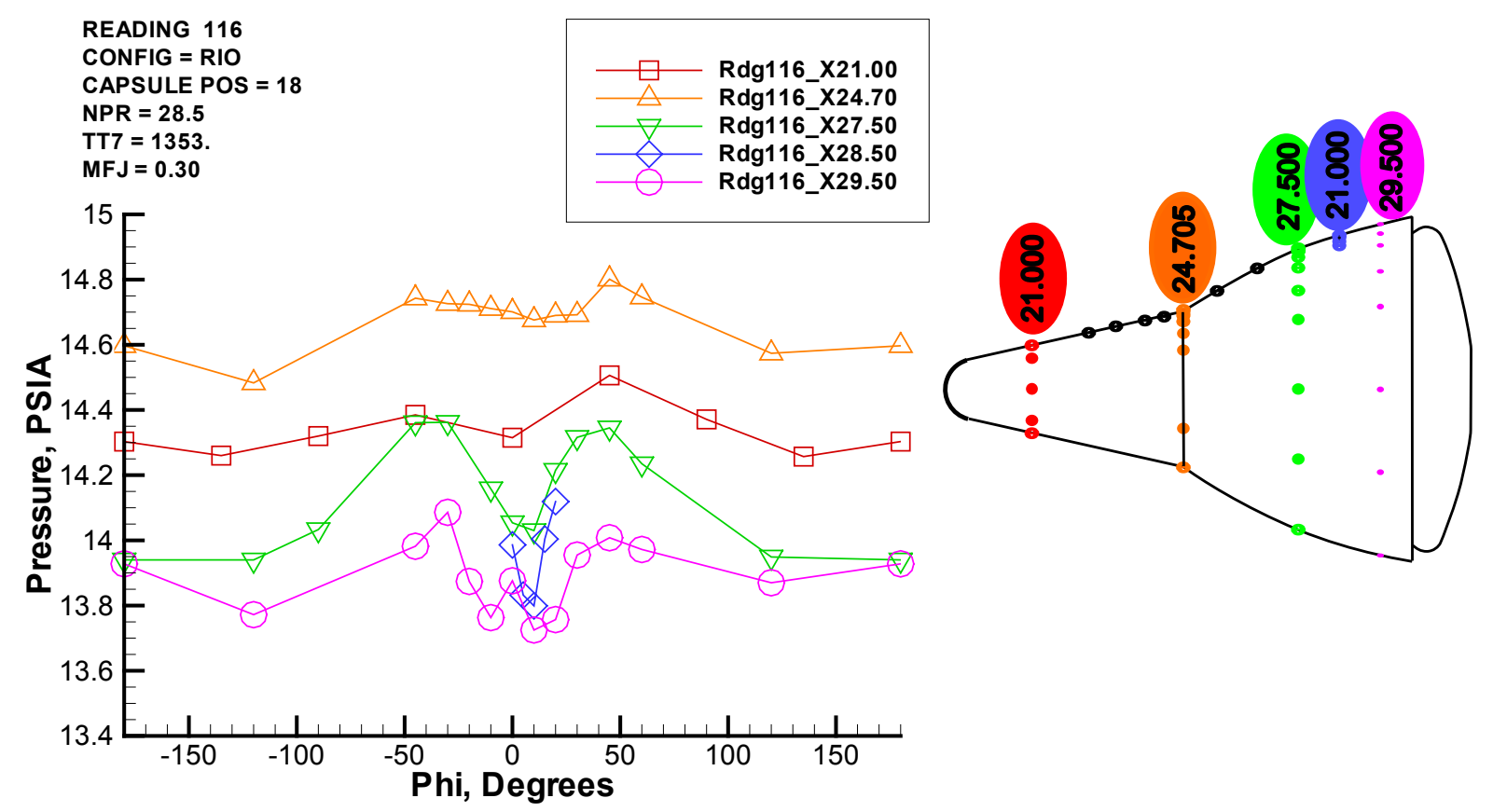

Figure 22.-Capsule pressures, $40^{\circ}$ nozzle, position 18 , hot.

\section{Capsule Surface Pressures}

$\begin{array}{ll}\text { READING 107 } & \text { READING 116 } \\ \text { CONFIG = RIO } & \text { CONFIG = RIO } \\ \text { CAPSULE POS =18 } & \text { CAPSULE POS = 18 } \\ \text { NPR }=28.5 & \text { NPR }=28.5 \\ \text { TT7 }=518 . & \text { TT7 }=1353 . \\ \text { MFJ }=0.30 & \text { MFJ }=0.30\end{array}$

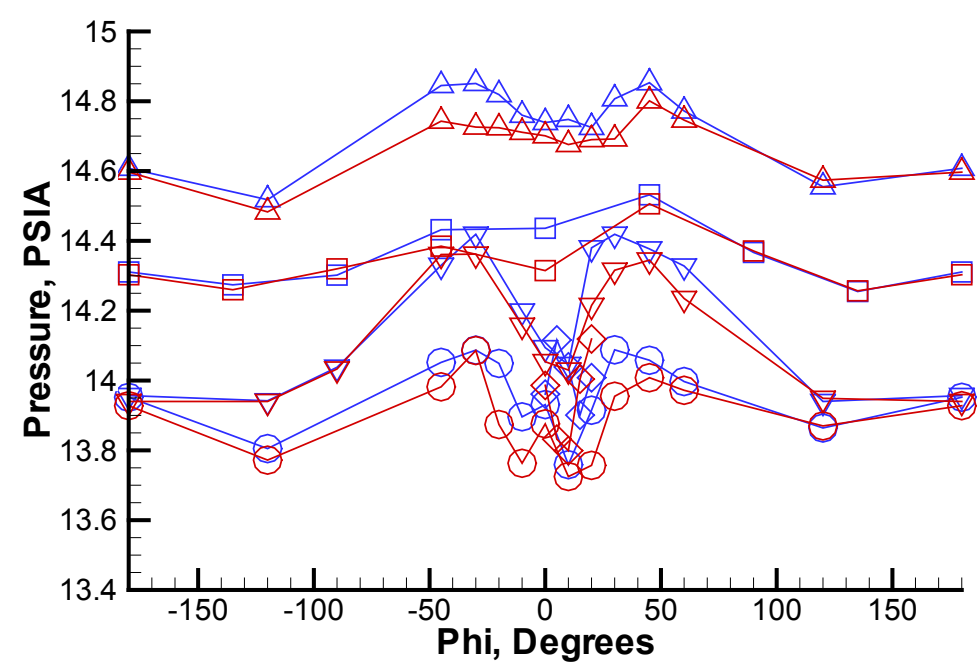

Figure 23.-Capsule pressures, $40^{\circ}$ nozzle, position 18 , cold and hot compared. 


\subsection{Concluding Remarks}

An experiment was performed to obtain detailed flow information for the validation of Computational Fluid Dynamics (CFD) modeling of the Ares I Launch Abort System. The experiment focused on a better understanding of the flow field details in the abort motor plume. The geometry and conditions of the experiment were designed not to exactly replicate those of the launch abort problem, but to provide a useful analog. Stereo Particle Image Velocimetry (SPIV) and surface pressure measurements were made.

A high quality data set has been created for hot, high-energy, angled jets in a cold cross flow with and without a bluff body. It is hoped that comparison of these data to calculations will lead to future improvements in turbulence modeling. At the time of this writing, the future of the Constellation program and the Ares I vehicle is uncertain. Regardless, the data from this experiment will be relevant to a variety of problems.

\section{References}

1. Liou, M.S. and Buning, P.G., "Contribution of the Recent AUSM Schemes to the OVERFLOW Code: Implementation and Validation," AIAA-2000-4404, 18th AIAA Applied Aerodynamics Conference, Denver, CO, Aug. 2000.

2. Olsen, M.E., and Coakley, T.J., "The Lag Model, a Turbulence Model for Non-equilibrium Flows," AIAA-2001-2564, 2001.

3. Menter, F.R., "Zonal Two Equation k- $\omega$ Turbulence Models for Aerodynamic Flows," AIAA Paper 93-2906, 1993.

4. Menter, F.R., "Two-Equation Eddy-Viscosity Turbulence Models for Engineering Applications," AIAA Journal, Vol. 32, pp. 269-289, 1994.

5. Baldwin, B.S. and Barth, T.J., A One-Equation Turbulence Transport Model for High Reynolds Number Wall-Bounded Flows, NASA TM-102847, 1990.

6. Cooper, B.A., "A Large Hemi-Anechoic Enclosure for Community-Compatible Aeroacoustic Testing of Aircraft Propulsion Systems," NASA TM-106015, 1993.

7. Soeder, R.H., Wnuk, S.P. and Loew, R.A., "Nozzle Acoustic Test Rig User Manual," NASA/TM2006-212939, 2006.

8. Castner, R.S., and Wolter, J.D., "Nozzle Acoustic Test Rig User Manual," NASA TM-113179, 1997.

9. Wernet, M., Wolter, J.D., Locke, R., Wroblewski, A., Childs, R., Nelson, A., "PIV Measurements of the CEV Hot Abort Motor Plume for CFD Validation," AIAA-2010-1031, 2010. 


\begin{tabular}{|c|c|c|c|c|c|}
\hline \multicolumn{5}{|c|}{ REPORT DOCUMENTATION PAGE } & $\begin{array}{l}\text { Form Approved } \\
\text { OMB No. 0704-0188 }\end{array}$ \\
\hline \multicolumn{6}{|c|}{ 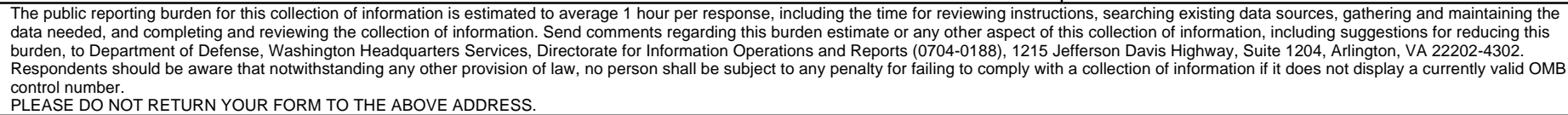 } \\
\hline \multicolumn{2}{|c|}{$\begin{array}{l}\text { 1. REPORT DATE }(D D-M M-Y Y Y Y) \\
01-03-2011\end{array}$} & \multicolumn{3}{|c|}{$\begin{array}{l}\text { 2. REPORT TYPE } \\
\text { Technical Memorandum }\end{array}$} & 3. DATES COVERED (From - To) \\
\hline \multirow{3}{*}{\multicolumn{5}{|c|}{$\begin{array}{l}\text { 4. TITLE AND SUBTITLE } \\
\text { Flow Field Characterization of an Angled Supersonic Jet Near a Bluff Body }\end{array}$}} & 5a. CONTRACT NUMBER \\
\hline & & & & & 5b. GRANT NUMBER \\
\hline & & & & & 5c. PROGRAM ELEMENT NUMBER \\
\hline \multirow{3}{*}{\multicolumn{5}{|c|}{$\begin{array}{l}\text { 6. AUTHOR(S) } \\
\text { Wolter, John, D.; Childs, Robert; Wernet, Mark, P.; Shestopalov, Andrea; Melton, John, E. }\end{array}$}} & 5d. PROJECT NUMBER \\
\hline & & & & & 5e. TASK NUMBER \\
\hline & & & & & $\begin{array}{l}\text { 5f. WORK UNIT NUMBER } \\
\text { WBS 644423.02.39.03.02 }\end{array}$ \\
\hline \multicolumn{5}{|c|}{$\begin{array}{l}\text { 7. PERFORMING ORGANIZATION NAME(S) AND ADDRESS(ES) } \\
\text { National Aeronautics and Space Administration } \\
\text { John H. Glenn Research Center at Lewis Field } \\
\text { Cleveland, Ohio 44135-3191 }\end{array}$} & $\begin{array}{l}\text { 8. PERFORMING ORGANIZATION } \\
\text { REPORT NUMBER } \\
\text { E-17563 }\end{array}$ \\
\hline \multirow{2}{*}{\multicolumn{5}{|c|}{$\begin{array}{l}\text { 9. SPONSORING/MONITORING AGENCY NAME(S) AND ADDRESS(ES) } \\
\text { National Aeronautics and Space Administration } \\
\text { Washington, DC 20546-0001 }\end{array}$}} & $\begin{array}{l}\text { 10. SPONSORING/MONITOR'S } \\
\text { ACRONYM(S) } \\
\text { NASA }\end{array}$ \\
\hline & & & & & $\begin{array}{l}\text { 11. SPONSORING/MONITORING } \\
\text { REPORT NUMBER } \\
\text { NASA/TM-2011-216958 }\end{array}$ \\
\hline \multicolumn{6}{|c|}{$\begin{array}{l}\text { 12. DISTRIBUTION/AVAILABILITY STATEMENT } \\
\text { Unclassified-Unlimited } \\
\text { Subject Categories: } 02 \text { and } 34 \\
\text { Available electronically at http://gltrs.grc.nasa.gov } \\
\text { This publication is available from the NASA Center for AeroSpace Information, 443-757-5802 }\end{array}$} \\
\hline \multicolumn{6}{|c|}{ 13. SUPPLEMENTARY NOTES } \\
\hline \multicolumn{6}{|c|}{$\begin{array}{l}\text { 14. ABSTRACT } \\
\text { An experiment was performed to acquire data from a hot supersonic jet in cross flow for the purpose of validating computational fluid } \\
\text { dynamics (CFD) turbulence modeling relevant to the Orion Launch Abort System. Hot jet conditions were at the highest temperature and } \\
\text { pressure that could be acquired in the test facility. The nozzle pressure ratio was } 28.5 \text {, and the nozzle temperature ratio was } 3 \text {. These } \\
\text { conditions are different from those of the flight vehicle, but sufficiently high to model the observed turbulence features. Stereo Particle } \\
\text { Image Velocimetry (SPIV) data and capsule pressure data are presented. Features of the flow field are presented and discussed. }\end{array}$} \\
\hline \multicolumn{6}{|c|}{$\begin{array}{l}\text { 15. SUBJECT TERMS } \\
\text { Computational fluid dynamics; Plumes; Particle image velocimetry; Turbulence models; Shear layer }\end{array}$} \\
\hline \multicolumn{3}{|c|}{ 16. SECURITY CLASSIFICATION OF: } & $\begin{array}{l}\text { 17. LIMITATION OF } \\
\text { ABSTRACT }\end{array}$ & $\begin{array}{l}\text { 18. NUMBER } \\
\text { OF }\end{array}$ & $\begin{array}{l}\text { 19a. NAME OF RESPONSIBLE PERSON } \\
\text { STI Help Desk (email:help@sti.nasa.gov) }\end{array}$ \\
\hline $\begin{array}{l}\text { a. REPORT } \\
\text { U }\end{array}$ & $\begin{array}{l}\text { b. ABSTRACT } \\
\text { U }\end{array}$ & $\begin{array}{l}\text { C. THIS } \\
\text { PAGE } \\
\text { U }\end{array}$ & UU & $\begin{array}{l}\text { PAGES } \\
23\end{array}$ & $\begin{array}{l}\text { 19b. TELEPHONE NUMBER (include area code) } \\
443-757-5802\end{array}$ \\
\hline
\end{tabular}



